\title{
Systems level analysis of two-component signal transduction systems in Erwinia amylovora: Role in virulence, regulation of amylovoran biosynthesis and swarming motility Youfu Zhao*1, Dongping Wang1, Sridevi Nakka1, George W Sundin ${ }^{2}$ and Schuyler S Korban ${ }^{3}$
}

Address: ${ }^{1}$ Department of Crop Sciences, University of Illinois at Urbana-Champaign, Urbana, IL 61801, USA, ${ }^{2}$ Department of Plant Pathology, Michigan State University, East Lansing, MI 48824, USA and ${ }^{3}$ Department of Natural Resources and Environmental Sciences, University of Illinois at Urbana-Champaign, Urbana, IL 61801, USA

Email: Youfu Zhao* - zhao888@illinois.edu; Dongping Wang - dwang22@illinois.edu; Sridevi Nakka - snakka2@illinois.edu; George W Sundin - sundin@msu.edu; Schuyler S Korban - korban@illinois.edu

* Corresponding author

Published: 26 May 2009

BMC Genomics 2009, 10:245 doi:10.1 186/147|-2164-10-245
Received: 30 December 2008

Accepted: 26 May 2009

This article is available from: http://www.biomedcentral.com/I47I-2/64/10/245

(c) 2009 Zhao et al; licensee BioMed Central Ltd.

This is an Open Access article distributed under the terms of the Creative Commons Attribution License (http://creativecommons.org/licenses/by/2.0), which permits unrestricted use, distribution, and reproduction in any medium, provided the original work is properly cited.

\begin{abstract}
Background: Two-component signal transduction systems (TCSTs), consisting of a histidine kinase (HK) and a response regulator (RR), represent a major paradigm for signal transduction in prokaryotes. TCSTs play critical roles in sensing and responding to environmental conditions, and in bacterial pathogenesis. Most TCSTs in Erwinia amylovora have either not been identified or have not yet been studied.
\end{abstract}

Results: We used a systems approach to identify TCST and related signal transduction genes in the genome of $E$. amylovora. Comparative genomic analysis of TCSTs indicated that $E$. amylovora TCSTs were closely related to those of Erwinia tasmaniensis, a saprophytic enterobacterium isolated from apple flowers, and to other enterobacteria. Forty-six TCST genes in E. amylovora including 17 sensor kinases, three hybrid kinases, 20 DNA- or ligand-binding RRs, four RRs with enzymatic output domain (EAL-GGDEF proteins), and two kinases were characterized in this study. A systematic TCST gene-knockout experiment was conducted, generating a total of 59 single-, double-, and triple-mutants. Virulence assays revealed that five of these mutants were nonpathogenic on immature pear fruits. Results from phenotypic characterization and gene expression experiments indicated that several groups of TCST systems in E. amylovora control amylovoran biosynthesis, one of two major virulence factors in $E$. amylovora. Both negative and positive regulators of amylovoran biosynthesis were identified, indicating a complex network may control this important feature of pathogenesis. Positive (non-motile, EnvZ/OmpR), negative (hypermotile, GrrS/GrrA), and intermediate regulators for swarming motility in $E$. amylovora were also identified.

Conclusion: Our results demonstrated that TCSTs in E. amylovora played major roles in virulence on immature pear fruit and in regulating amylovoran biosynthesis and swarming motility. This suggested presence of regulatory networks governing expression of critical virulence genes in $E$. amylovora. 


\section{Background}

Prokaryotes use their small size and metabolic diversity to dominate every conceivable niche on earth. A large part of this success comes from the evolution of elaborate sensory systems to monitor and respond to dramatic fluctuations in their environment. Primary means of signal transduction in bacteria involve two-component signal transduction systems (TCSTs) [1,2]. The term "two-component" was coined in 1986 to describe a new class of regulatory systems found in bacteria; today, two-component systems represent major paradigms for signal transduction in prokaryotes and in lower eukaryotes $[3,4]$. The prototypical two-component system consists of a histidine kinase protein (HK) containing a conserved kinase core and a response regulator protein (RR) containing a conserved regulatory domain $[4,5]$. Extracellular stimuli are sensed by, and serve to modulate HK activities. The HK is autophosphorylated at a histidine residue, creating a highenergy phosphoryl group that is subsequently transferred to an aspartate residue in the RR via a reaction catalyzed by the RR itself. Phosphotransfer to the RR leads to activation of a downstream effector domain that elicits a specific response $[1,4]$.

Two-component systems are distributed at varying frequencies among organisms of all domains, including Eubacteria, Archaea, and Eukarya [1,3]. The availability of complete genome sequences has allowed for a definitive assessment of the prevalence of two-component proteins. There are $30 \mathrm{HKs}$ (five of which are hybrid kinases) and 32 RRs in Escherichia coli [6]. However, the number of twocomponent proteins differs greatly among bacteria. Often, parasitic bacteria encode fewer signaling proteins than relatively free-living bacteria [7]. Among sequenced plant pathogenic bacteria, the number of TCST genes is quite different. For example, the xylem-limited Xylella fastidiosa has the fewest TCST genes; whereas, the relatively adaptable Pseudomonas syringae and Xanthomonas spp. have the largest number of TCST genes $[8,9]$. Perhaps, the most attractive reason for studying two-component systems in bacteria is that TCST systems are used by pathogenic bacteria to control expression of virulence factors required for infection. Many such TCST systems are identified in both human and animal pathogens and in plant pathogens $[7,10]$. The Agrobacterium tumefaciens VirA/VirG system, the GacA/GacS of both Pseudomonas sp. and Pectobacterium carotovora, and the RpfCG of Xanthomonas spp. and X. fastidiosa are probably the most well-known and studied TCST systems involved in virulence gene expression in plant pathogens [10-12]. However, most of these studies focused on one or a few TCSTs. Only recently has genomewide analysis of TCSTs in plant pathogenic bacteria become possible due to increased availability of whole genome sequences $[8,9,13]$.
E. amylovora is the causal agent of fire blight, a devastating necrotic disease affecting apple, pear, and other rosaceous plants. Fire blight is one of the most important bacterial plant diseases worldwide that has a significant economic impact, resulting in crop losses of millions of dollars per year [14]. As a member of the Enterobacteriaceae, E. amylovora is related to many important human and animal pathogens such as Es. coli, Salmonella enterica, Shigella flexneri, Yersinia enterocolitica, and Y. pestis. Like many other Gram-negative plant pathogenic bacteria, E. amylovora utilizes both a type III secretion (T3SS) apparatus to deliver effector proteins into host plant cells, and the extracellular polysaccharide (EPS) amylovoran to cause disease [15-17]. In E. amylovora, structural components of T3SS encoded by the Hrp regulon are regulated by the two-component system HrpX and HrpY, which direct the expression of the NtrC family $\sigma^{54}$-dependent, enhancerbinding protein HrpS [18]. Both HrpY and HrpS function in the activation of expression of the alternate sigma factor HrpL, thereby regulating various genes and operons of the Hrp regulon. Expression of $h r p X$ and $h r p S$ is regulated by low $\mathrm{pH}$, low nutrients, and low temperature conditions, mimicking the plant apoplast [18]. The biosynthesis of amylovoran is regulated by another TCST system, the RcsCDB phosphorelay system [17]. Recently, we identified several TCST genes including $h r p X$, grrS, and envZ that are induced during infection of host tissue in E. amylovora, indicating that TCSTs are key players in controlling the expression of virulence factors required for infection, and thus we hypothesize that there are likely networks controlling virulence gene expression [19]. However, other TCSTs in E. amylovora have either not been identified or have not yet been studied. This prompted us to use a systems approach to explore the function of TCSTs in E. amylovora. Understanding the genetics and molecular mechanisms of E. amylovora signaling will greatly enhance the likelihood of developing novel methods of controlling the disease.

The EnvZ-OmpR and GrrS-GrrA (also called GacSA, BarAUvrY) are two widely-distributed and well-studied TCSTs in $\gamma$-proteobacteria. They represent those paradigms of signal transduction systems having pleiotropic effects, thus suggesting both systems are global regulators $[2,20]$. EnvZ is a transmembrane sensor that predominantly responds to acidic $\mathrm{pH}$ conditions and changes in osmolarity, and subsequently phosphorylates OmpR. The EnvZ-OmpR system has been originally reported to govern the expression of $o m p C$ and $o m p F$ genes, encoding two major outermembrane porins [21]. In addition to its role in porin osmoregulation, OmpR is involved in regulating various cellular components including flagellar gene expression, fatty acid transport, curli fibre formation, and cell division as a dual regulator; i.e., negative or positive [22]. In Salmo- 
nella spp., OmpR-EnvZ regulates another TCST system SsrA-SsrB, that in turn regulates the T3SS produced by Salmonella pathogenicity island 2 (SPI-2) [23-26]. OmpR also negatively regulates expression of invasin in Yersinia enterocolitica and the T3SS in P. syringae $[27,28]$.

GacS and GacA homologs have been identified in many Gram-negative bacterial genera, including Azotobacter, Erwinia, Escherichia, Legionella, Pectobacterium, Pseudomonas, Salmonella, Serratia, and Vibrio [12,20,29]. The sensor kinase GacS was initially discovered as a key regulator of virulence in the plant pathogen $P$. syringae [see review [12]]. The GacSA system has since been reported to regulate an array of phenotypes, including biofilm formation, alginate biosynthesis, production of toxins and extracellular enzymes [30,31], proteases, siderophores, swarming motility [32], and type III secretion [10,29,3335]. Similar to EnvZ-OmpR, GacSA also has a dual regulatory function; i.e., as a positive or negative regulator. The GacS/GacA (BarA/UvrY) system positively controls the expression of one to five genes specifying small RNAs (sRNAs), thus upregulating the productions of proteins that are otherwise repressed by small RNAs (RsmA/CsrA) $[32,36]$. Most gacS/gacA mutants demonstrate reduced production of virulence factors and reduced virulence in a variety of host-pathogen systems [12,20]. An alternative scenario is that the GacSA cascade downregulates the expression of flagellar genes in P. fluorescens or Es. coli [20].

In this study, our genome-wide analysis, using the recently closed genome sequence of E. amylovora Ea273 http://www.sanger.ac.uk/Projects/E amylovora/ identified a total of 46 TCST genes in E. amylovora including 17 sensor kinases, 20 response regulators, three hybrid HKs, four RRs with enzymatic output domain (EAL-GGDEF proteins), and two kinases. A comparative genomic analysis of TCSTs was then conducted in related enterobacteria enabling classification of the TCSTs in E. amylovora. A total of 59 deletion mutants were generated, and their contribution to virulence, amylovoran biosynthesis, and swarming motility was characterized. Our findings suggested that TCSTs in E. amylovora played a major role in virulence and in the regulation of amylovoran biosynthesis and swarming motility. This indicated that networks of gene regulation existed in E. amylovora that respond to different environmental and host signals.

\section{Results}

Identification and comparison of TCSTs in E. amylovora We utilized two approaches to identify HKs and RRs in the genome of E. amylovora. First, using a candidate gene approach, known HK and RR sequences from Es. coli K12 and $P$. carotovora pv. atroseptica SCRI1043 were used to search the closed genome sequence of E. amylovora http:// www.sanger.ac.uk/Projects/E amylovora/. Second, based on conserved domains of known HKs and RRs, other putative HKs and RRs in E. amylovora were identified and confirmed by searching the complete genome sequences for proteins containing HK and RR domains using Pfam Hidden Markov Model (HMM) profiles and BLASTP. As a result, we identified 46 TCST and other related signal transduction genes in E. amylovora (Table 1 and Table S1, [see Additional file 1]), excluding two sets of chemotaxis genes (cheABRWYZ). These putative regulatory genes represented $1.36 \%$ of the genome (3367 genes) [37]. Among them, 17 are sensor kinases, three hybrid HKs, 20 DNA-or ligand-binding RRs, four RRs with enzymatic output domain (EAL-GGDEF proteins), and two putative kinases (Table 1).

When compared to TCSTs in other enterobacteria, the majority of TCSTs in E. amylovora have counterparts in related enterobacteria, including Dickeya dadantii (Erwinia chrysanthemi) 3937, P. carotovora subsp. atroseptica SCRI1043, Erwinia tasmaniensis Et1/99, and Es. coli K12 (Table 2 and Table S1, [see Additional file 1]). Only one $\mathrm{HK}$ and RR pair ( $y p d A B)$ in E. tasmaniensis is not present in E. amylovora Ea273 (Table 2). The number of TCSTs in E. amylovora is the lowest among other sequenced related plant pathogenic enterobacteria and Es. coli (Table S1, [see Additional file 1]). BLAST searches revealed that the HKs and RRs in E. amylovora shared the highest amino acid (aa) identity/similarity to those of E. tasmaniensis Et1/99, an epiphytic bacterium isolated from apple flowers in Australia [38], except for HrpX/Y which shared the highest aa identity/similarity to those in Erwinia pyrifoliae, a related blight pathogen of Asian pear (Table 2). It is interesting to note that HrpXY, which regulates T3SS gene expression in plant pathogenic enterobacteria, is the only TCST that is not present in other mammalian enterobacterial pathogens [39].

\section{Classification of HKs and RRs in E. amylovora}

In general, HKs are highly variable in amino acid sequence length; whereas, RRs are highly conserved in their receiver domain (REC). Classification of HKs is usually based on alignment of residues surrounding the $\mathrm{H}$ box that contains the conserved His residue within the histidine kinase domain (HisKA) [9,40]. Multiple sequence alignment using Clustal X has classified the HKs of E. amylovora into four groups [40]. Among them, 15 belong to groups IA (11), IB (3), and IC (1); and one (DcuS), two (NarQ and HrpX), and one (YehU) belong to groups II, III, and IV HKs, respectively (Table S1, [see Additional file 1] and Figure S1, [see Additional file 2]). This is the first time that HrpX has been classified as a type III HK. However, RcsD (also known as YojN), containing 
Table I: TCSTs and other signal transduction genes in Erwinia amylovora and mutant construction

\begin{tabular}{|c|c|c|}
\hline Gene/Operon ${ }^{\mathrm{a}}$ & HK/RR/Hybrid/kinaseb & Mutants constructed ${ }^{c}$ \\
\hline $\operatorname{arcB}, \operatorname{arc} A$ & HK, RR & $\Delta \operatorname{arcB}, \Delta \operatorname{arcA}$ \\
\hline baeSR & $\mathrm{HK}, \mathrm{RR}$ & $\Delta$ baeS, $\Delta$ baeR, $\Delta$ baeSR \\
\hline$c p \times A \mid R I$ & $H K, R R$ & $\Delta c p \times A I, \Delta c p \times R I, \Delta c p \times A R I$ \\
\hline$c p \times A 2 R 2$ & $H K, R R$ & $\Delta \mathrm{cp} \times \mathrm{A} 2, \Delta \mathrm{cp} \times \mathrm{R} 2, \Delta \mathrm{cp} \times \mathrm{AR} 2$ \\
\hline dcuSR & HK, RR & $\Delta$ dcuS, $\Delta$ dcuR, $\Delta$ dcuSR \\
\hline envZlompR & $H K, R R$ & $\Delta$ envZ, $\Delta$ ompR, $\Delta$ envZ/ompR \\
\hline grrS, grrA & HK hybrid, RR & $\Delta \mathrm{grrS}, \Delta \mathrm{grrA}$ \\
\hline$h r p X Y, h r p S$ & $\mathrm{HK}, \mathrm{RR}, \mathrm{EBP}$ & $\Delta$ hrpX, $\Delta$ hrpY, $\Delta$ hrpXY, $\Delta$ hrpXYS \\
\hline$k d p D, k d p E$ & HK, RR & $\Delta \mathrm{kdpD}, \Delta \mathrm{kdpE}$ \\
\hline narQP & $H K, R R$ & $\Delta$ narQ, $\Delta$ narP, $\Delta$ narQP \\
\hline phoQP & HK, RR & $\Delta \mathrm{phoQ}, \Delta \mathrm{phoP}, \Delta \mathrm{phoQP}$ \\
\hline phoRB & $H K, R R$ & $\Delta \mathrm{phoR}, \Delta \mathrm{phoB}, \Delta \mathrm{phoRB}$ \\
\hline pmrBA & HK hybrid, RR & $\Delta$ pmrB, $\Delta$ pmrA, $\Delta$ pmrBA \\
\hline$r C s C D B$ & HK hybrid, HPT, RR & $\Delta \mathrm{rcsD}, \Delta \mathrm{rcsB}, \Delta \mathrm{rcs} C, \Delta \mathrm{rcsBD}$ \\
\hline$r s t B, r s t A$ & HK, RR & $\Delta r s t B, \Delta r s t A$ \\
\hline yehUT & $\mathrm{HK}, \mathrm{RR}$ & $\Delta$ yehU, $\Delta$ yehT, $\Delta$ yehUT \\
\hline$y f h K A$ & $H K, R R$ & $\Delta y f h K, \Delta y f h A, \Delta y f h K A$ \\
\hline \multicolumn{3}{|c|}{ Other signal transduction genes used in this studyb } \\
\hline eamlR & $A H L, R R$ & $\Delta$ eaml, $\Delta$ eamR \\
\hline $\operatorname{lux} Q, \operatorname{lux} P$ & $A 12$ sensor kinase, $R R$ & $\Delta$ luxQ, $\Delta$ luxP \\
\hline Spkl & Serine kinase & $\Delta$ spkl \\
\hline ybjN & Kinase & $\Delta y b j N$ \\
\hline yciR & GGDEF-EAL & $\Delta y c i R$ \\
\hline yddV & GGDEF & $\Delta y d d V$ \\
\hline yegE & GGDEF & $\Delta$ yegE \\
\hline yoad & EAL & $\Delta$ yoaD \\
\hline
\end{tabular}

a Genes for one TCST system are listed separately if they are not encoded within an operon in the genome. Otherwise, TCSTs are listed as an operon if genes are present together. Mutants for $n$ trBC were not constructed.

${ }^{b}$ All TCSTs are sensor kinases and their corresponding DNA-binding response regulators. We included two sets of quorum sensing genes and four RRs with enzymatic output domain (EAL-GGDEF proteins) and two kinases. EBP: NtrC family of enhancing-binding protein. HPT: Histidine phosphotransfer domain; AHL: Acyl-homoserine lactone; GGDEF: Diguanylate cyclase; EAL: Type I c-di-GMP phosphodiesterase.

c Mutant designation see Table 3.

a histidine phosphotransfer (HPt) domain, but lacking a conserved histidine residue in the HisKA domain, could not be classified.

Analysis of the domain architecture of E. amylovora HKs, by either searching the Conserved Domain Databases (CDD) [41] or using the SMART program [42] http:// smart.embl-heidelberg.de/, has revealed that all HKs in $E$. amylovora, except for HrpX and NtrB, contain one to three hydrophobic transmembrane (TM) helices within the Nterminal sensor region. This indicates that these HKs are periplasmic sensors. HrpX and NtrB contain two and one PAS domain (initially found in PER, ARNT, and SIM proteins), respectively, within the $\mathrm{N}$-terminal sensor region, indicating that they are soluble and cytoplasmic proteins that sense intracellular signals [18]. The YehU contains a 5TMR-LYT (5 TM receptor domain, LytS-like) sensory input domain before the two TM helices, thus indicating that the YehU is an intramembrane sensor.

Often, RRs are classified into families based on their output domains and domain combinations [43]. By search- ing the SMART program and conducting a structural similarity of C-terminal output domains $[4,43]$, it is revealed that 20 RRs contain either DNA- or ligand-binding output domains in E. amylovora (Table S1, [see Additional file 1]). Among them, eleven, four, two, and one are further classified into OmpR-, NarL-, NtrC-, and LytR-like proteins, respectively (Table S1, [see Additional file 1]). These RRs belong to four major families of RRs found in prokaryotes and account for about $64 \%$ of all RRs identified thus far [43]. In addition, four RRs (YciR, YddV, YegE, and YoaD) contain enzymatic output domains including GGDEF and EAL domains (Table 1). The GGDEF and EAL domains have diguanylate cyclase and Type I c-di-GMP phosphodiesterase activity, respectively, and these proteins are involved in regulating virulence functions in some plant pathogens [44].

\section{Systematic deletion of TCSTs and related signaling genes,} and their roles in virulence on immature pear fruit

To pursue comprehensive identification of two-component signaling pathways required for virulence, swarming motility, and amylovoran biosynthesis in E. amylovora, 
Table 2: Comparison of E. amylovora and E. tasmaniensis TCST and other signal transduction genes ${ }^{\mathrm{a}}$

\begin{tabular}{|c|c|c|c|c|c|}
\hline Gene $^{b}$ & $\begin{array}{l}\text { Length of deduced } \\
\text { Amino acidc }\end{array}$ & $\begin{array}{l}\text { aa Identityl } \\
\text { Similarity (\%) }\end{array}$ & Gene $^{b}$ & $\begin{array}{l}\text { Length of deduced } \\
\text { Amino acidc }\end{array}$ & $\begin{array}{l}\text { aa Identityl } \\
\text { Similarity (\%)d }\end{array}$ \\
\hline $\operatorname{arcB}$ & 779 & $93 / 95$ & $\operatorname{arcA}$ & 238 & $96 / 99$ \\
\hline baes & 461 & $89 / 93$ & baeR & 235 & $88 / 94$ \\
\hline $\operatorname{grrS}($ barA $)$ & 909 & $91 / 94$ & grrA (Eta_20780) & 219 & $94 / 98$ \\
\hline$c p \times A l$ & 459 & $96 / 98$ & $c p \times R I$ & 233 & $95 / 97$ \\
\hline cpxA2 (Eta_I0960) & 450 & $82 / 88$ & cpxR2 (Eta_10950) & 226 & $88 / 93$ \\
\hline dcus & 546 & $79 / 86$ & $d c u R$ & 239 & $86 / 93$ \\
\hline envZ & 449 & $95 / 97$ & $o m p R$ & 239 & $100 / 100$ \\
\hline$h r p X$ & 494 & $89 / 93$ & $h r p Y$ & 213 & $94 / 96$ \\
\hline$k d p D$ & 890 & $95 / 97$ & $k d p E($ Eta_23200) & 226 & $89 / 92$ \\
\hline IuxQ (Eta_II 320) & $419(420)$ & $89 / 93$ & luxP (Eta_II350) & 258 & $74 / 89$ \\
\hline narQ & 330 & N/A & narP & $209(210)$ & $71 / 83$ \\
\hline$n t r B$ & 349 & $96 / 98$ & $n t r C$ & 469 & $98 / 98$ \\
\hline phoQ & 481 & $92 / 96$ & phop & 222 & $95 / 98$ \\
\hline phoR & 437 & $88 / 92$ & phoB & 229 & $96 / 98$ \\
\hline pmrB & 350 & $81 / 89$ & pmrA & 219 & $94 / 98$ \\
\hline $\operatorname{rcs} C$ & $885(890)$ & $88 / 93$ & $r c s B$ & 215 & $99 / 100$ \\
\hline $\operatorname{rcs} D(y o j N)$ & $987(95 I)$ & $84 / 91$ & eamR $(s d i A)$ & 240 & $84 / 92$ \\
\hline$r s t B$ & 426 & $92 / 96$ & rstA & 242 & $93 / 97$ \\
\hline ybjN (Eta_2I780) & 159 & $91 / 96$ & Spkl (Eta_06360) & 468 & $91 / 92$ \\
\hline yddV (hmsT) & 365 & $81 / 88$ & yegE & 848 (877) & $78 / 88$ \\
\hline yehU & $564(562)$ & $84 / 90$ & yehT & 239 & $80 / 89$ \\
\hline$y f h K$ & $463(475)$ & $87 / 91$ & yfhA (Eta_10100) & 444 & $93 / 96$ \\
\hline yoaD (rtn) & $516(523)$ & $81 / 89$ & yciR (Eta_30620) & $818(820)$ & $82 / 91$ \\
\hline
\end{tabular}

a Sequences for E. amylovora TCST genes are from the whole genomic sequence of E. amylovora http://www.sanger.ac.uk/Projects/E amylovora/. One TCTS system (ypdAB) in E. tasmaniensis is not present in E. amylovora Ea273. Two sets of CheABRWYZ exist in E. amylovora, but only one set in E. tasmaniensis.

$\mathrm{b}$ In parentheses is gene or gene number for the corresponding gene in $E$. tasmaniensis.

$c$ The number in parentheses is the length of deduced amino acid for the corresponding protein in $E$. tasmaniensis which differs from those in $E$. amylovora.

d All data are the highest aa similarity and identify found in NCBI database as of today except for HrpXY which share the highest aa identity/ similarity to those in $E$. pyrifoliae (98/99\%; $99 / 99 \%$, respectively). N/A: not available.

deletion mutants were generated for those genes/operons identified above, and also included $h r p S$ and eamI. Deletions were made using the Lambda-Red recombinase technique, as previously described for Es. coli and E. amylovora [45-47]. A total of 59 single-, double- and triple- stable deletion mutants were generated (Table 1 and Table 3 ). For these mutants, the majority of the coding region of each gene or operon was deleted and replaced by the $\mathrm{Cm}^{\mathrm{R}}$ or $\mathrm{Km}^{\mathrm{R}}$ marker gene, except for the first and last $50 \mathrm{nt}$ of the gene or operon, thus minimizing any polar effects of the mutation.

For prokaryotes, genes for cognate pairs of HKs and RRs are typically encoded together in a single operon [1]. Because of this unique feature for HKs and RRs, and the potential cross-talk between different HKs and RRs, these single deletion mutants generated in this study have been designed to have little or no effect on expression/function of the cognate gene in the operon. Furthermore, operon deletion mutants have been generated so that phenotypes of single gene deletion mutants could be compared with those of operon deletion mutants to determine whether or not there is cross-talk between HKs and RRs. All mutants and their designations are listed in Table 3.

To determine the role of deletion mutants in E. amylovora virulence, an assay, routinely used to evaluate virulence of E. amylovora WT strains, of all 59 TCST mutants on immature pear fruits was conducted $[19,46,48]$. Mutants and WT strains were inoculated on immature pears as described, and disease development was assessed for up to eight days. Results showed that five mutants, including three single ( $r c s B, r c s C, r c s D$ mutant), one double ( $r c s B D)$, and one triple mutant ( $h r p X Y S)$, were non-pathogenic on immature pears (Table 3 ). However, $h r p X, h r p Y$, and $h r p X Y$ mutants remained to exhibit full-virulence, as that of WT, on immature pear fruit (Table 3). Previous genetic studies have shown that a mutation in $r c s B$ renders E. amylovora nonpathogenic and abolishes amylovoran production [49]. Our results further demonstrated that the RcsCDB phosphorelay system was essential for virulence in E. amylovora [17]. In addition, all other mutants induced similar symptoms to the WT strain on immature pear fruit (Table 3). 
Table 3: E. amylovora TCTS mutants and their phenotypes

\begin{tabular}{|c|c|c|c|c|c|c|c|}
\hline $\begin{array}{l}\text { Gene/Oper- } \\
\text { on }^{\mathrm{a}}\end{array}$ & $\begin{array}{c}\text { Mutant } \\
\text { designation }\end{array}$ & $\begin{array}{l}\text { Virulence } \\
\text { assayb }\end{array}$ & $\begin{array}{c}\text { Amylovoran } \\
\text { production } \\
(48 \mathrm{~h}) \\
\left(\mathrm{OD}_{600}\right)^{\mathrm{c}}\end{array}$ & $\begin{array}{c}\text { Significance } \\
\text { levele }^{\text {Sevice }}\end{array}$ & $\begin{array}{r}\text { Distance } \\
\text { it }\end{array}$ & $\begin{array}{l}\text { ming motil- } \\
\text { cm) }\end{array}$ & $\begin{array}{c}\text { Significance } \\
\text { levele }^{\text {enc }}\end{array}$ \\
\hline WT & & +++ & $0.08 \pm 0.002$ & nop & $\mathrm{C}$ & $2.7 \pm 0.15$ & cde \\
\hline ams & Z0II8 $8 \mathrm{ams}$ & --- & $0.002 \pm 0.0005$ & $r$ & ND & ND & ND \\
\hline flhD & Z2946 $\Delta$ flhD & +++ & ND & ND & C & $0.7 \pm 0$ & w \\
\hline fliA & Z2986 ffliA & +++ & ND & ND & C & $0.7 \pm 0$ & w \\
\hline $\operatorname{arcA}$ & ZI306 $\Delta$ arcA & +++ & $0.053 \pm 0.0001$ & $\mathrm{qr}$ & $\mathrm{C}$ & $1.23 \pm 0.09$ & uv \\
\hline $\operatorname{arcB}$ & ZOII7 $\Delta \mathrm{arcB}$ & +++ & $0.067 \pm 0.0002$ & $p q$ & $\mathrm{C}$ & $1.83 \pm 0.28$ & $\mathrm{qr}$ \\
\hline bae $R$ & Z3I20 2 baeR & +++ & $0.14 \pm 0.045$ & klmn & 1 & $1.87 \pm 0.25$ & $\mathrm{qr}$ \\
\hline baes & Z3119 & +++ & $0.13 \pm 0.03$ & klmn & i & $2.07 \pm 0.06$ & nopq \\
\hline baeSR & $\begin{array}{l}\text { Z3219- } \\
\text { 20வbaeSR }\end{array}$ & +++ & $0.1 \pm 0.01$ & $\operatorname{Imn}$ & 1 & $2.07 \pm 0.06$ & nopq \\
\hline$c p \times A I$ & Z0686 $\Delta \mathrm{cpxAI}$ & +++ & $0.09 \pm 0.014$ & nop & 1 & $1.40 \pm 0.22$ & tu \\
\hline$c p \times A I R I$ & $\begin{array}{l}\text { Z0686- } \\
87 \Delta c p \times A R I\end{array}$ & +++ & $0.055 \pm 0.003$ & $\mathrm{pqr}$ & 1 & $1.33 \pm 0.05$ & uv \\
\hline$c p \times R I$ & Z0687 $\Delta \mathrm{cpxRI}$ & +++ & $0.08 \pm 0.008$ & nop & 1 & $1.16 \pm 0.13$ & v \\
\hline$c p \times A 2$ & $\mathrm{Z} 3367 \Delta \mathrm{cp} \times \mathrm{A} 2$ & +++ & $0.35 \pm 0.023$ & hgi & 1 & $2.5 \pm 0.4$ & efghi \\
\hline$c p \times A 2 R 2$ & $\begin{array}{l}\text { Z3367- } \\
68 \Delta \text { cpxAR2 }\end{array}$ & +++ & $0.29 \pm 0.07$ & $\mathrm{i}$ & 1 & $2.07 \pm 0.34$ & opqr \\
\hline$c p \times R 2$ & $\mathrm{Z3368 \Delta cp \times R2}$ & +++ & $0.35 \pm 0.058$ & hgi & I & $2.5 \pm 0.14$ & efgh \\
\hline dcuR & Z236I $\Delta$ dcuR & +++ & $0.198 \pm 0.01$ & $\mathrm{k}$ & 1 & $2.2 \pm 0.17$ & ijklm \\
\hline dcus & $\mathrm{Z} 2362 \Delta$ dcuS & +++ & $0.171 \pm 0.02$ & $\mathrm{kl}$ & 1 & $2.07 \pm 0.32$ & ijklm \\
\hline dcuSR & $\begin{array}{l}\text { Z236I- } \\
62 \Delta \text { dcuSR }\end{array}$ & +++ & $0.256 \pm 0.02$ & j & 1 & $2.23 \pm 0.38$ & mnop \\
\hline eaml & 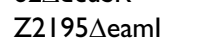 & +++ & $0.256 \pm 0.046$ & j & 1 & $2.23 \pm 0.12$ & $\mathrm{ijk} / \mathrm{m}$ \\
\hline eamR & Z2194 4 eamR & +++ & $0.544 \pm 0.1$ & de & 1 & $2.03 \pm 0.31$ & pqr \\
\hline envZ & Z0270 $\Delta$ envZ & +++ & $1.55 \pm 0.06$ & c & $\mathrm{C}$ & $1.03 \pm 0.11$ & v \\
\hline envZlompR & $\begin{array}{l}\text { Z0270-7I } \\
\Delta \text { envZ/ompR }\end{array}$ & +++ & $1.7 \pm 0.05$ & a & C & $1.03 \pm 0.11$ & v \\
\hline ompR & Z027I $\Delta o m p R$ & +++ & $1.63 \pm 0.06$ & $b$ & $\mathrm{C}$ & $1.03 \pm 0.11$ & v \\
\hline grrA & $\mathrm{Z} 2198 \Delta \mathrm{grrA}$ & +++ & $1.58 \pm 0.15$ & bc & $\mathrm{C}$ & $3.15 \pm 0.07$ & $\mathrm{a}$ \\
\hline grrs & Z3742 $\Delta$ grrS & +++ & $1.56 \pm 0.09$ & c & C & $3.2 \pm 0.05$ & $\mathrm{a}$ \\
\hline hrpX & Z3962 $\Delta$ hrpX & +++ & $0.69 \pm 0.11$ & d & I & $1.73 \pm 0.15$ & rs \\
\hline$h r p Y$ & Z3963 $\mathrm{hrpY}$ & +++ & $0.471 \pm 0.05$ & $\mathrm{e}$ & 1 & $2.0 \pm 0.0$ & opqr \\
\hline$h r p X Y$ & $\begin{array}{l}\text { Z3962-63 } \\
\Delta \text { hrpXY }\end{array}$ & +++ & $0.45 \pm 0.09$ & ef & i & $2.33 \pm 0.15$ & hijkl \\
\hline$h r p X Y S$ & $\begin{array}{l}\text { Z3962-64 } \\
\Delta \text { hrpXYS }\end{array}$ & --- & $0.4 \pm 0.09$ & gh & 1 & $2.27 \pm 0.15$ & hijkl \\
\hline$k d p D$ & $\mathrm{Z} 04 \mid 4 \Delta \mathrm{kdpD}$ & +++ & $0.372 \pm 0.02$ & hgi & 1 & $2.13 \pm 0.12$ & nopq \\
\hline$k d p E$ & 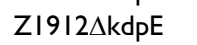 & +++ & $0.09 \pm 0.035$ & no & 1 & $1.43 \pm 0.19$ & tu \\
\hline $\operatorname{luxP}$ & Z3324 $\Delta$ luxP & +++ & $0.419 \pm 0.12$ & $g$ & 1 & $1.87 \pm 0.23$ & rs \\
\hline $\operatorname{lux} Q$ & Z3327 $\Delta$ luxQ & +++ & $0.625 \pm 0.11$ & de & 1 & $1.9 \pm 0.17$ & $\mathrm{qr}$ \\
\hline narP & Z3390 $\Delta$ narP & +++ & $0.1 \pm 0.001$ & Imn & i & $2.2 \pm 0.0$ & klmno \\
\hline narQ & Z3389 $\Delta$ narQ & +++ & $0.08 \pm 0.003$ & Imn & 1 & $2.4 \pm 0.1$ & fghij \\
\hline narQP & $\begin{array}{l}\text { Z3389-90 } \\
\Delta \text { narQP }\end{array}$ & +++ & $0.08 \pm 0.002$ & nop & 1 & $2.27 \pm 0.25$ & ghijkl \\
\hline phoB & Zl675 $\Delta$ phoB & +++ & $0.145 \pm 0.003$ & klmn & 1 & $2.6 \pm 0.2$ & defg \\
\hline phoR & Zl676 phoR & +++ & $0.366 \pm 0.01$ & hgi & I & $2.75 \pm 0.15$ & cd \\
\hline phoRB & $\begin{array}{l}\text { Zl675-76 } \\
\Delta \text { phoRB }\end{array}$ & +++ & $0.312 \pm 0.01$ & hi & 1 & $2.7 \pm 0.1$ & cde \\
\hline phop & Z2324 $\Delta$ phoP & +++ & $0.15 \pm 0.02$ & $\mathrm{klm}$ & 1 & $2.45 \pm 0.17$ & cdef \\
\hline phoQ & Z2323 $\Delta$ phoQ & +++ & $0.106 \pm 0.01$ & Imno & 1 & $2.25 \pm 0.23$ & efghi \\
\hline phoQP & $\begin{array}{l}\text { Z2323-24 } \\
\Delta \text { phoQP }\end{array}$ & +++ & $0.18 \pm 0.002$ & $\mathrm{jk}$ & i & $2.25 \pm 0.15$ & ijklm \\
\hline pmrA & Z0089 $\Delta$ pmrA & +++ & $0.05 \pm 0.02$ & pqr & I & $2.3 \pm 0.19$ & hijkl \\
\hline pmrB & $\mathrm{Z} 0090 \Delta \mathrm{pmrB}$ & +++ & $0.10 \pm 0.01$ & Imno & 1 & $2.40 \pm 0.17$ & defgh \\
\hline pmrBA & $\begin{array}{l}\text { Z0089-90 } \\
\text { SpmrBA }\end{array}$ & +++ & $0.07 \pm 0.01$ & opq & i & $2.3 \pm 0.20$ & fghij \\
\hline$r c s B$ & $\mathrm{Z} 3206 \Delta \mathrm{rcs} B$ & --- & $0.002 \pm 0.0005$ & $r$ & I & $2.51 \pm 0.17$ & efghi \\
\hline $\operatorname{rcs} C$ & $\mathrm{Z} 3207 \Delta \operatorname{rcs} C$ & --- & $0.4 \pm 0.04$ & $\mathrm{fg}$ & 1 & $2.45 \pm 0.2$ & fghij \\
\hline
\end{tabular}


Table 3: E. amylovora TCTS mutants and their phenotypes (Continued)

\begin{tabular}{|c|c|c|c|c|c|c|c|}
\hline rcsD (yojN) & $\mathrm{Z} 3205 \Delta \mathrm{rcs} D$ & --- & $0.002 \pm 0.0002$ & $r$ & 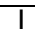 & $2.48 \pm 0.28$ & efghi \\
\hline$r c s D B$ & $\begin{array}{l}\text { Z3205-06 } \\
\Delta \mathrm{rcsBD}\end{array}$ & --- & $0.003 \pm 0.0001$ & $r$ & I & $2.43 \pm 0.11$ & fghijk \\
\hline$r s t A$ & Z265I $\Delta$ rstA & +++ & $0.359 \pm 0.045$ & hgi & I & $1.6 \pm 0$ & st \\
\hline$r s t B$ & $\mathrm{Z} 2662 \Delta \mathrm{rstB}$ & +++ & $0.1 \pm 0.032$ & $\operatorname{Imn}$ & I & $2.03 \pm 0.06$ & opqr \\
\hline spkl & 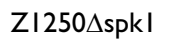 & +++ & $0.17 \pm 0.04$ & $\mathrm{kl}$ & I & $2.58 \pm 0.14$ & cdef \\
\hline ybjN & Z2074 $\Delta y b j N$ & +++ & $1.65 \pm 0.12$ & a & I & $2.05 \pm 0.26$ & Imno \\
\hline yciR & Z0955 $\Delta$ yciR & +++ & $0.111 \pm 0.0012$ & Imno & I & $1.9 \pm 0.08$ & pqr \\
\hline$y d d V$ & $\mathrm{Z} \mid 215 \Delta y d d V$ & +++ & $0.043 \pm 0.001$ & $q r$ & C & $2.9 \pm 0.14$ & bc \\
\hline yegE & Z3II3 4 yegE & +++ & $0.22 \pm 0.007$ & j & I & $2.9 \pm 0.14$ & bc \\
\hline yehT & Z3996 & +++ & $0.186 \pm 0.026$ & k & I & $2.5 \pm 0.2$ & efghi \\
\hline yehU & Z3995 $\triangle$ yehT & +++ & $0.15 \pm 0.04$ & $\mathrm{klm}$ & I & $2.33 \pm 0.21$ & fghij \\
\hline yehUT & $\begin{array}{l}\text { Z3995-96 } \\
\text { AyehUT }\end{array}$ & +++ & $0.15 \pm 0.004$ & $\mathrm{klm}$ & I & $2.4 \pm 0.17$ & fghij \\
\hline$y f h A$ & Z3498 $\mathrm{yfhA}$ & +++ & $0.07 \pm 0.012$ & opq & 1 & $2.3 \pm 0.1$ & hijkl \\
\hline$y f h K$ & 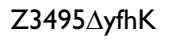 & +++ & $0.06 \pm 0.002$ & $\mathrm{pq}$ & I & $2.33 \pm 0.25$ & fghij \\
\hline yfhKA & $\begin{array}{l}\text { Z3495-98 } \\
\Delta \text { yfhKA }\end{array}$ & +++ & $0.062 \pm 0.0005$ & $\mathrm{pq}$ & I & $2.17 \pm 0.12$ & Imno \\
\hline yoaD & Z0355 $\triangle$ yоаD & +++ & $0.22 \pm 0.008$ & j & I & $2.4 \pm 0.37$ & ghijkl \\
\hline
\end{tabular}

a ams operon encodes amylovoran biosynthesis. The entire operon ( $a m s A-L ; ~ I 5.8 \mathrm{~kb}$ ) was deleted in the ams mutant [47]. flhD and fliA encode two regulators of flagella biosynthesis. These three mutants were used as negative controls for amylovoran biosynthesis and swarming motility, respectively.

b Virulence assay was performed using immature pear fruits as described. +++: pathogenic as WT; ---: non-pathogenic.

c Amylovoran production was measured $48 \mathrm{hr}$ post inoculation. ND: not determined.

d Distance of swarming motility was measured $48 \mathrm{hr}$ post inoculation. Original circle was about $0.6 \mathrm{~cm}$ in diameter. I: irregular movement; C: circular. ND: not determined.

e Values within the amylovoran production and distance of swarming motility columns followed by the same letter are not significantly different according to one way ANOVA and student-Newmans-Kleus test $(P=0.05)$.

\section{Phenotypic analysis of deletion mutants}

All generated mutants did not exhibit any distinctive phenotypes on rich LB medium, except for a single mutant which was mucoid ( $y b j N$ mutant). Therefore, phenotypes of the 59 deletion mutant strains were evaluated using a swarming plate assay [50,51]. WT cells can swarm via the combined effects of flagellar motility, chemotaxis, and growth, thus creating a circular colony. Defects in cell motility, chemotaxis, or growth can produce alterations in swarming size or density [51]. For E. amylovora WT and mutant strains, bacterial suspensions were plated onto swarming agar plates containing $0.3 \%$ agar, as previously described $[50,51]$. Swarming diameter and density were determined following incubation at $28^{\circ} \mathrm{C}$ for up to $72 \mathrm{hr}$, and three different swarming phenotypes were identified. Two mutants, grrA and grrS, exhibited substantially larger and lower density swarms than the WT (Figure 1A; Table 3 , significance level a). In addition, three mutants, envZ, $o m p R$, and $e n v Z / o m p R$ double-mutant, showed dramatic reduction in swarm size, but with increased density (Figure 1B; Table 3, significance level v). All these five mutants exhibited circular swarming (Figure 1A and 1B). A third group of mutants showed smaller swarms, colonies exhibited irregular circular patterns, and these included $\operatorname{arc} A B$, baeRS, cpxA1R1, kdpE, luxPQ, rstAB, and $y c i R$ mutants (Figure 1C; Table 3, significance levels o to $\mathrm{u}$ ). Although the distance of the cPXA1R1 mutants had similar significant level as that of envZ/ompR mutants at $48 \mathrm{hr}$, these mutants were included in the third group due to its irregular move- ments and with increased distance at $72 \mathrm{hr}$ in contrast to envZ/ompR mutants which remained the same at $72 \mathrm{hr}$ (Figure 2B). The rest of mutants showed even less change in swarm distance. As negative controls, all flagella-deficient mutants, flhDC and fliA, were non-motile on swarming plates (Figure 1D).

As shown in Figure 1A, grrS/grrA mutant strains showed precocious swarming and moved faster than the WT strain, with a diameter of $1.7 \mathrm{~cm}$ within $24 \mathrm{hr}$ compared to $1 \mathrm{~cm}$ for the WT strain, from an original spot of $0.6 \mathrm{~cm}$ in diameter (Figure 2A). The swarming distance was 3.2 and $4.8 \mathrm{~cm}$ for $\mathrm{grrS} / \mathrm{grrA}$ mutants and 2.7 and $3.8 \mathrm{~cm}$ for WT strain, respectively, at 48 and $72 \mathrm{hr}$ (Figure 2A). When grrS and grrA mutants were complemented with their own gene cloned from the WT strain, the hyper-motile phenotype was restored in these mutants with a swarming distance, $\sim 2.8 \mathrm{~cm}$ after $48 \mathrm{hr}$ of incubation, similar to that of the WT strain (data not shown). In contrast, envZ/ompR mutants showed reduced swarming even after $72 \mathrm{hr}$ (Figure $2 \mathrm{~B}$ ), and colonies exhibited more dense and fuzzy appearance. The diameter for envZ/ompR mutants was about $0.8,1.0$, and $1.0 \mathrm{~cm}$ for 24 to $72 \mathrm{hr}$, from an original spot of $0.6 \mathrm{~cm}$ in diameter, respectively (Figure 2B). When envZ/ompR mutants were complemented by their own gene cloned from the WT strain, the 'low-motile' phenotype was partially restored. The diameter (about $1.5 \mathrm{~cm}$ after $48 \mathrm{hr}$ of incubation) for the complemented mutant strains was comparable to that of the WT strain (Data not 


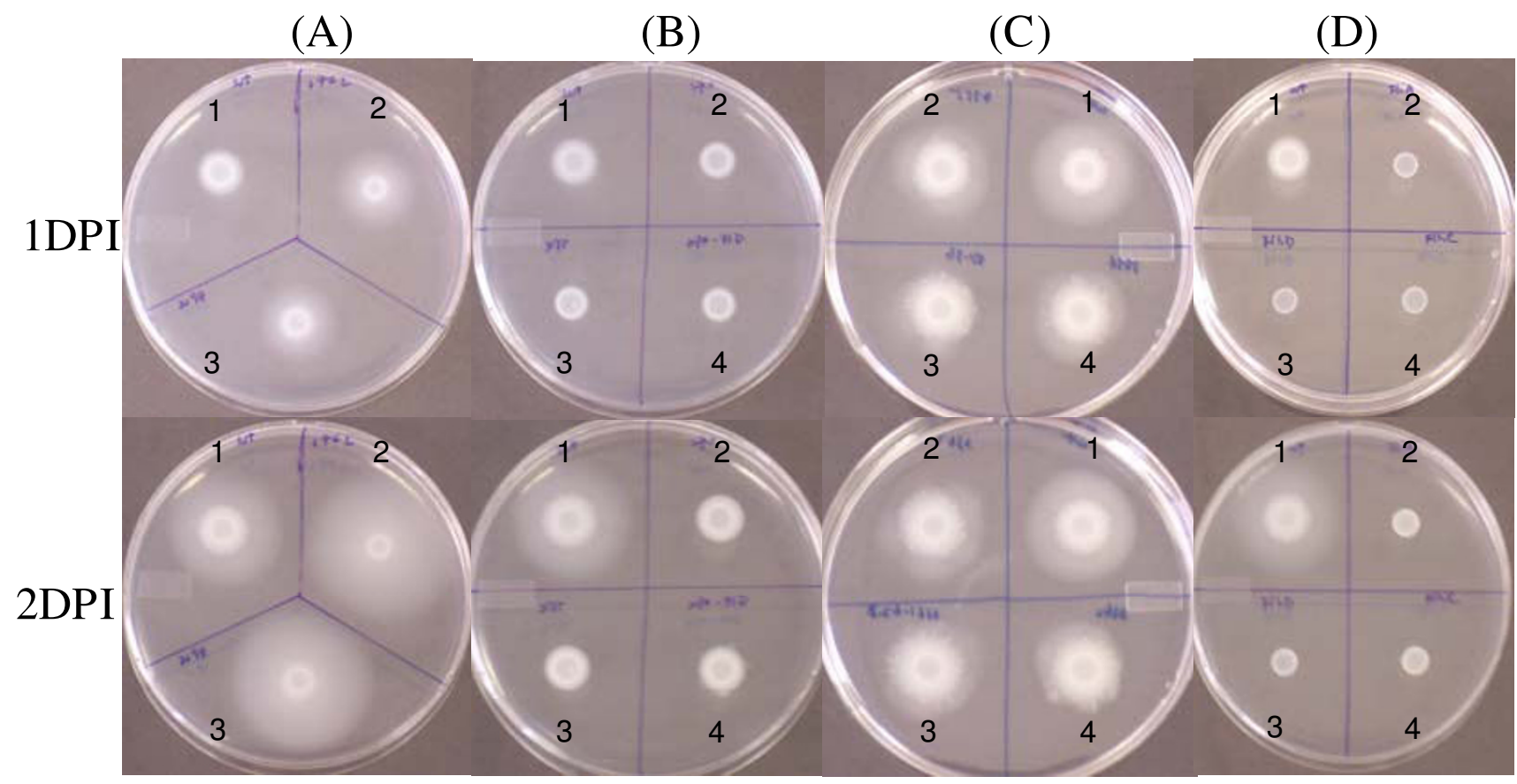

\section{Figure I}

Comparison of motility on swarming plates for WT and TCST mutants. Bacterial strains were spotted on the swarming plate $(0.3 \%$ agar $)$ and incubated at $28^{\circ} \mathrm{C}$. Photos were taken at one or two days post inoculation. DPI: days post inoculation. Al to DI: WT strain; A2: grrS mutant; A3: grrA mutant; B2: envZ mutant; B3: ompR mutant; B4: envZlompR double mutant; $\mathbf{C 2}$ to $\mathbf{C 4}$ : representative mutants with irregular movements at two days post inoculation; $\mathbf{D 2}$ to $\mathbf{D 4}$ : flhD, flhC and fliA mutant, respectively. Flagella mutants were used as negative controls.

shown). However, the swarming phenotype remained different between envZ/ompR mutants and those of flhDC and fliA mutants, which exhibited no movement and maintained the original size of 0.6 to $0.7 \mathrm{~cm}$ in diameter (Figure 1BD). In summary, these results demonstrated that EnvZ/OmpR acts as a positive regulator of swarming motility, while GrrS/GrrA is a negative regulator of swarming motility in E. amylovora. These findings demonstrated that additional TCST genes might also control swarming motility in E. amylovora.

\section{Regulation of amylovoran biosynthesis}

Based on the virulence assay, the RcsCDB system that regulates amylovoran biosynthesis is essential for virulence in E. amylovora. Phenotypes of the 59 deletion mutant strains were further evaluated by measuring amylovoran biosynthesis in vitro. The amylovoran concentration in the supernatant of bacterial cultures was quantitatively determined using a turbidity assay with cetylpyrimidinium chloride (CPC), as previously described [52]. In this screening, four groups of mutants exhibiting varying levels of amylovoran production in vitro were identified (Table 3). For Group I, three mutants $(r c s B, r c s D$, and $r c s B D$ ) exhibited lack of amylovoran production (Table 3, significance level r); For Group II, six mutants (grrA, grrS, $y b j N$, envZ, ompR, and envZ/ompR double-mutant) showed a dramatic increase in amylovoran production, about 20fold, compared to that of the WT (Figure 3A; Table 3, significance levels a to c); Group III mutants demonstrated increased production of amylovoran, from 2- to 8-fold, compared to that of the WT, and these included $h r p X$, $h r p Y, h r p X Y, h r p X Y S, r c s C$, luxPQ, and eamIR (Table 3, significance levels d to j). Group IV mutants did not show much difference in amylovoran production when compared to that of $\mathrm{WT}$, and these included $\operatorname{pmr} A B$, narPQ, and $y f h A K$ (Table 3 , significance levels $\mathrm{k}$ to $\mathrm{p}$ ). As a negative control, an amylovoran operon deletion mutant, ams, lacked amylovoran production (Figure 3A; Table 3, significance level r) [17,47].

For group I mutants, we have recently described how the RcsCDB phosphorelay system regulates amylovoran biosynthesis [17]. This study focused on group II mutants, except for the $y b j N$ mutant, which will be reported in the future. Amylovoran production of five mutants, including grrA, grrS, envZ, ompR, and the envZ/ompR double-mutant, was partially complemented by their own gene/operon cloned from the WT strain. As shown in Figure 3A, complemented strains produced slightly less amylovoran than that of the mutant strains. To correlate amylovoran pro- 
(A)

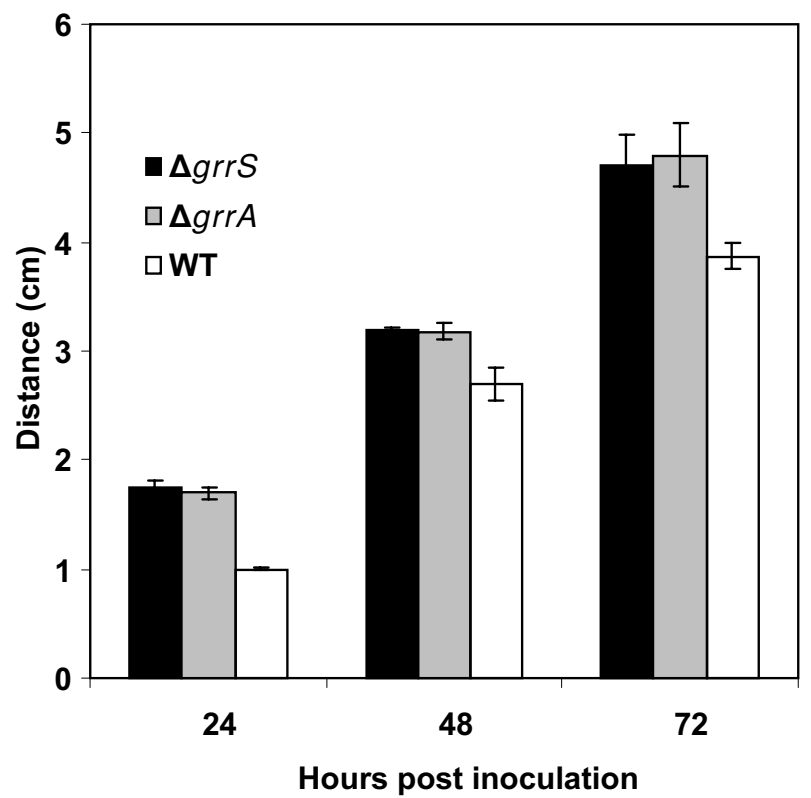

(B)

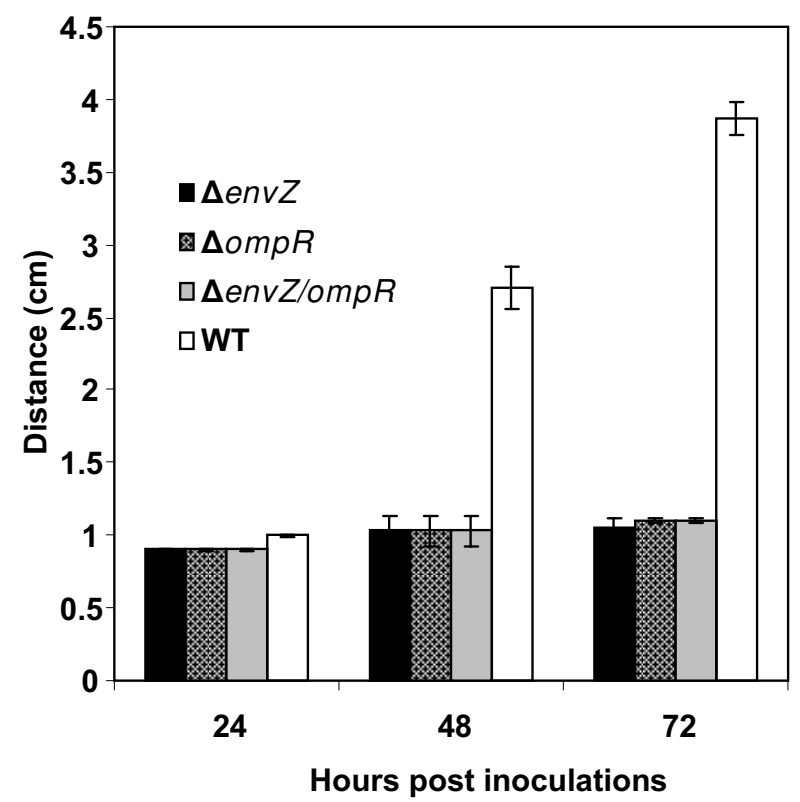

Figure 2

Comparison of the swarming distance of WT and

TCST mutants. The diameters of the swarming circle were measured 24, 48 and 72 hrs after incubation. The experiments were repeated at least three times.

duction with amylovoran biosynthesis gene expression [17], the level of expression of the amsG gene, the first gene in the ams (amylovoran) operon, was measured using GFP as a reporter in two RR mutants ( $\mathrm{grrA}$ and $o m p R$ ). GFP intensity was measured in the WT and in mutants containing the ams $G$ promoter-GFP fusion using flow cytometry [17]. The amsG gene was expressed at a basal level in the WT strain, with a GFP intensity value of 1.7 (geometric mean), compared to a geometric mean value of 1.5 for the control vector. The geometric mean value of the GFP intensity of the ams $G$ promoter was 26.2 and 60.5 for $o m p R$ and grrA mutants, respectively (Figure $3 \mathrm{~B})$. These results indicated that amylovoran production was negatively regulated by both EnvZ/OmpR and GrrA/S systems, and a regulatory network might be regulating amylovoran production in E. amylovora.

\section{Discussion}

In this study, 46 TCSTs have been identified in E. amylovora, a pathogen of rosaceous plants which mainly resides in the plant xylem, but can also grow epiphytically on stigmas of flowers. Compared to other plant pathogenic enterobacteria such as $D$. dadantii and $P$. carotovora subsp. atroseptica, both of which can survive not only in plants, but also in soil, or the animal counterpart Es. coli, the number of TCSTs present in E. amylovora is relatively small, thus may reflecting the particular host niche for this pathogen. Furthermore, the genome size (3.9 Mbp) of $E$. amylovora is also the smallest among sequenced enterobacterial plant and mammalian pathogens [53]. However, E. amylovora still maintains both enterobacterial-specific TCSTs (such as the Rcs system) [54] and plant enterobacterial-specific ones (such as HrpXY) [39].

On the other hand, E. amylovora has almost the same number of TCSTs as that found in E. tasmaniensis, a saprophytic bacterium isolated from apple flowers in Tasmania, Australia [38]. Since both bacteria occupy the same ecological niche during colonization and can grow epiphytically on flowers, these bacteria might have developed and maintained similar TCSTs. This suggests that TCSTs may be evolutionarily maintained to cope with similar environmental and plant host signals in closely related bacteria. It is interesting to note that fire blight is endemic to North America, and it has subsequently spread to Europe and New Zealand in the 1950s and in 1917, respectively, but it has not yet been reported in Australia [14]. It is possible that these two bacteria may have not yet encountered each other, as the distribution of E. tasmaniensis outside of Australia remains unknown. Surprisingly, we found that the majority of TCSTs in these two bacteria share a high level of aa similarity and identity. These results suggest that similar TCSTs might play important roles for the survival and proliferation among closely-related bacteria in similar plant niches.

Currently, several thousands of TCSTs have been identified in sequenced bacterial genomes [55-57]. Although the basic biochemistry of TCSTs is well understood, some structural insights in phosphorylation-dependent changes of TCST domains are variable. Domain architecture has proven particularly informative for analyzing multido- 
(A)

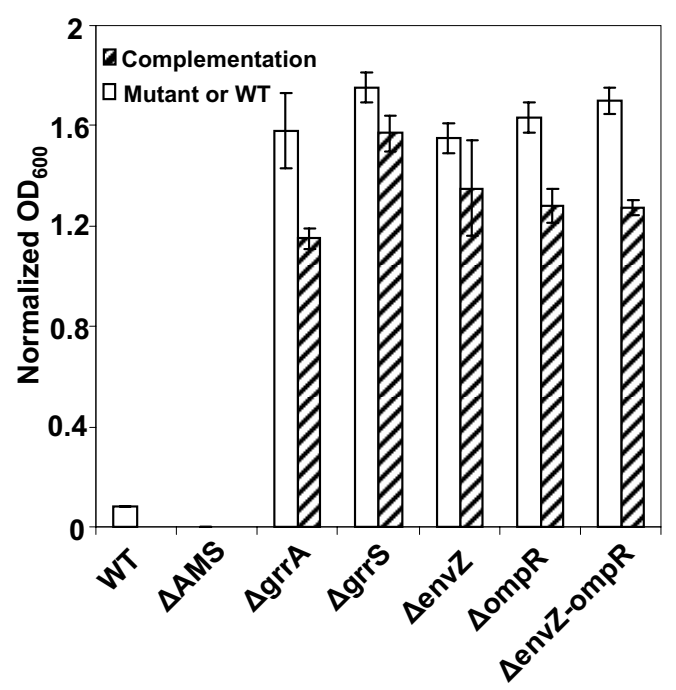

(B)
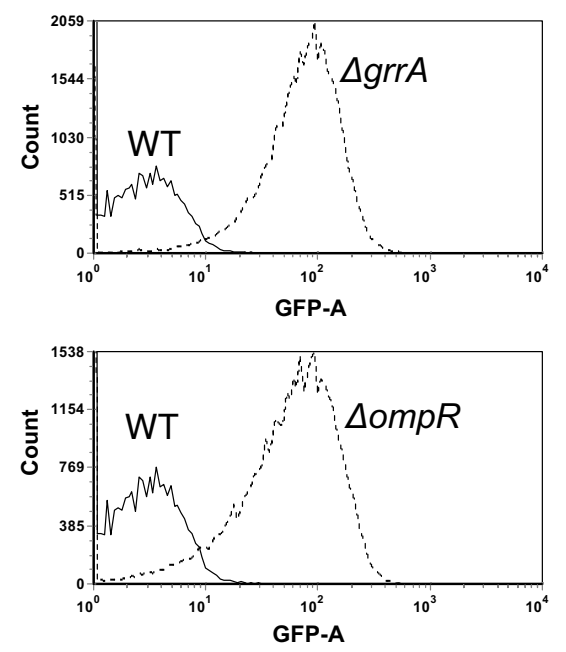

Figure 3

TCSTs regulate amylovoran biosynthesis and gene expression. (A) Amylovoran production of $E$. amylovora WT and TCST mutants in vitro. Bacterial strains were grown in MBMA media with $1 \%$ sorbitol for $48 \mathrm{hrs}$ at $28^{\circ} \mathrm{C}$ with shaking. The amount of amylovoran was measured with the CPC assay and normalized to a cell density of I. Amylovoran operon (amsA-L) deletion mutant ( $\triangle a m s)$ was used as a negative control [47]. (B) Gene expression of the ams $G$ gene in WT and TCST mutants in vitro. GFP intensity in WT and TCST mutants containing ams $G$ promoter-gfp fusion plasmid was measured by flow cytometry. GFP-A: Green fluorescence protein absorbance; Count: Number of cells.

main proteins involved in signal transduction and in predicting the functions of these signal transduction proteins $[43,58]$. In RRs, structural characterization of DNA-binding domains has revealed several variations on the common helix-turn-helix (HTH) theme, such as NarL- and
OmpR-types. Recently, many novel conserved domains have been described such as PAS, GAF, GGDEF, EAL, and HD-GYP, thereby affirming the complexity of bacterial signaling systems $[43,58]$. In E. amylovora, most HKs belong to four common HK groups, and are periplasmic sensors. Moreover, most RRs in this bacterium are OmpR, NarL-, NtrC-, and LytR-like proteins, the four most common families of DNA-binding RRs found in prokaryotes [43]. These results indicate that E. amylovora has maintained some basic signal transduction systems for the bacterium to survive. Phylogenetic and genomic analyses have revealed co-evolutionary relationships between cognate HKs and RRs. This seems obvious in E. amylovora as orphan HKs and RRs are rare.

It is well understood that TCSTs are involved in regulating virulence gene expression in plant bacterial pathogens [10]. Previous reports on TCSTs have demonstrated the importance of TCSTs in the virulence of bacterial plant pathogens. However, data on complete or global virulence regulation networks are lacking. A recent study by Qian et al. [13] provides a useful beginning towards a better understanding of the regulatory networks involved. A genome-wide mutagenesis of all $54 \mathrm{RRs}$ in X. campestris pv. campestris has revealed that two novel RRs are involved in virulence, thus facilitating future studies on signaling networks in this bacterium [13]. In this study, we have utilized a reverse genetic approach and constructed $59 \mathrm{HK}$ and RR mutants in E. amylovora, which will also provide valuable tools for future global gene expression assays using microarrays to deduce signaling networks in this bacterium.

Early studies have revealed that in E. amylovora, the Hrp T3SS, which delivers effector proteins into host plants, and the EPS amylovoran are two major virulence factors $[52,59,60]$. Previous reports have also indicated that the RcsCDB phosphorelay system regulates amylovoran biosynthesis, while the two-component system HrpXY regulates $h r p$-T3SS gene expression. Recently, we have further demonstrated that the Rcs system is essential for virulence in E. amylovora and may play a role in the survival of the pathogen [17]. Mutations in the Rcs system have rendered the organism non-pathogenic [17]. In this study, we have found that $h r p X, h r p Y$ and $h r p X Y$ mutants remain virulent, and could induce a spotty weak hypersensitive response (HR) on tobacco (Figure S2A, [see Additional file 2]); while, a hrpXYS triple mutant has a normal Hrp- phenotype. It is interesting to note that, in a previous report, Tn5-insertional mutants of $h r p Y$ have been reported to be non-pathogenic, and could not induce an HR on tobacco [18]. Two classes of $h r p X$ insertional mutants have been identified, one similar to the $h r p Y$ mutant and the other that continue to cause disease and induce a spotty HR on tobacco [18]. Similar observations have been reported in 
Pantoea stewartii subsp. stewartii, causal agent of Stewart's wilt of corn [61]; wherein, Tn5-insertional $h r p X$ and $h r p Y$ mutants exhibit a Hrp- phenotype and in-frame deletion $h r p X$ mutants show reduced virulence. Since the $h r p X Y$ is transcribed as an operon, it is possible that Tn 5 insertion could cause polar effects on the downstream genes such as hrpS (Figure S2B, [see Additional file 2]). Indeed, a recent study indicates that the hrp regulatory genes in $P$. stewartii subsp. stewartii participate in a novel regulatory loop that upregulates itself by readthrough transcription of $h r p L$ into hrpXYS [62].

It has been proposed that in E. amylovora, both HrpY and HrpS regulate $h r p L$, encoding the master regulator of T3SS, and that the effects of HrpY and HrpS are additive [18]. Subsequent studies of $P$. stewartii subsp. stewartii, D. dadantii, and Pantoea herbicola pv. gyposophilae have demonstrated that HrpY initially activates hrpS by binding to its promoter, and then the HrpL is activated by HrpS as well as by other regulatory genes $[39,63]$. Furthermore, it has been reported that HrpY in $D$. dadantii acts as both a positive and negative regulator [39]. In P. stewartii subsp. stewartii, besides the HrpY binding site, additional sequences further upstream of the hrpS promoter are also required for $h r p S$ expression, suggesting that unknown regulatory proteins may act cooperatively with HrpY [63]. Microarray studies suggest that $h r p L$ represents only one branch of the regulatory pathways downstream of hrpRS, and a large number of genes regulated by HrpRS are $h r p L-$ independent in P. syringae [64]. In our study, HrpX, HrpY, and HrpS also act as negative regulators, as $h r p X, h r p Y$, $h r p X Y$, and hrpXYS mutants produce more amylovoran. Our virulence tests suggest that the T3SS remains functional in $h r p X, h r p Y$, and $h r p X Y$ deletion mutants, but not in the hrpXYS mutant, whereby HrpS and HrpL may be activated by other unknown regulators except that production and/or translocation of $\operatorname{HrpN}$ (Harpin) in tobacco is severely attenuated as showed in an HR assay (Figure S2A, [see Additional file 2]). It is possible that host signals affecting gene expression may also be different in tobacco.

Various models have proposed that HrpX senses environmental signals in the plant apoplast or the Hrp-inducing medium to phosphorylate HrpY [18,34,35]. However, domain structure analysis has indicated that HrpX is a soluble cytoplasmic protein, and may sense intracellular signals. This suggests that other signaling pathways may also be involved in activating $h r p X Y, h r p S$, or $h r p L$ by sensing outside signals to regulate T3SS. Since the expression of HrpX, HrpS, and HrpL is regulated by low $\mathrm{pH}$, also corresponding to conditions under which OmpR-EnvZ and GrrS-GrrA are activated, our results further suggest that both OmpR-EnvZ and GrrS-GrrA can regulate the hrpXY operon or $h r p S$ either directly or indirectly as reported in other plant pathogenic bacteria $[10,28,33,34]$. Further studies are needed to dissect the roles of OmpR-EnvZ and GrrS-GrrA in regulating T3SS.

Several regulatory genes have been previously reported to control amylovoran biosynthesis in E. amylovora, including the Rcs system, RcsA, Lon protease, and H-NS protein $[17,50,65]$. Here, we have further identified several groups of regulators, including both negative and positive regulators. These regulators may form a network that governs the production of amylovoran under different conditions to benefit pathogen survival or pathogenesis. Regulatory cascades are also likely to occur as global regulators such as OmpR-EnvZ and GrrS-GrrA may control expression of other regulatory genes or proteins, such as $h r p X Y$ and quorum sensing systems, as reflected in the amount of amylovoran produced in these mutants. However, we cannot rule out that cross-talk between different TCSTs may further complicate this scenario. Our study indicates that regulation of amylovoran biosynthesis is highly complex and further suggests that the pathogen has developed a system to control this major virulence factor.

Swarming is a flagella-driven form of motility for movement across solid surfaces as a group [66-70]. Swarmer cells are normally hyperflagellated and require extracellular components such as EPS and surfactants that enable mass migration [71,72]. Previous studies have identified several global regulators in Es. coli and in other bacteria, including the Rcs system, OmpR and GrrSA, known to influence flagella biosynthesis, especially the master regulator flhDC $[71,73]$. In this study, we have identified both negative (GrrSA) and positive (EnvZ/OmpR) regulators of swarming motility. It is easy to accept that the GacSA system may negatively regulate flagella biosynthesis, thus rendering grrSA mutants hypermotile. It is also obvious that flagella biosynthesis is not impaired in the envZ-ompR mutants as the swarming phenotype is different between the envZ-ompR mutants and the flhDC-fliA mutants. The obvious question that arises as to why envZ-ompR mutants are non-motile although they produce prolonged flagella. A recent study in Salmonella typhimurium has reported that mutations in chemotaxis pathways are impaired for swarming motility and further revealed a role of flagellum in sensing external wetness [72]. It has been proposed that swarming requires a fluid environment generated as bacteria extract water from the underlying agar gel [74]. Flagella are designed to work in this aqueous environment; that is swarming cells move in a thin layer of fluid over the surface of the agar. Further studies have revealed that the wetting agent that draws water out of the underlying agar is an osmotic agent [74]. It is likely that in our envZ-ompR mutants, this unknown osmotic agent provides a signal for EnvZ-OmpR system that may regulate chemotaxis response or creates high osmolarity so that water can be 
removed from the agar, thus affecting swarming motility. Further studies are needed to clarify this hypothesis.

\section{Conclusion}

In summary, we have identified and classified TCSTs, and have systematically generated TCST deletion mutants in $E$. amylovora. The mutants generated will serve as resources for future exploration of TCSTs in E. amylovora. In-depth characterization of deletion mutants and global gene expression will be our next goal. Our current data provide experimental evidence that TCSTs, especially those global regulators such as the Rcs system, EnvZ-OmpR and GrrAGrrS, play important roles in virulence and in regulating virulence factors such as amylovoran production and swarming motility. These findings also suggest that multiple TCSTs may form complex and highly connected circuits and signaling networks in this important pathogen.

\section{Methods}

\section{Bacterial stains and culture media}

Bacterial strains and plasmids used in this study are listed in Table 4. The LB medium was used routinely for culturing E. amylovora. When necessary, the following antibiotics were added to the medium: $20 \mu \mathrm{g} \mathrm{ml}^{-1}$ kanamycin and chloramphenical, and $100 \mu \mathrm{g} \mathrm{ml}^{-1}$ ampicillin. Amylovoran production was determined by growing bacteria in MBMA medium (3 g $\mathrm{KH}_{2} \mathrm{PO}_{4}, 7 \mathrm{~g} \quad \mathrm{~K}_{2} \mathrm{HPO}_{4,} 1 \mathrm{~g}$ $\left[\mathrm{NH}_{4}\right]_{2} \mathrm{SO}_{4}, 2 \mathrm{ml}$ glycerol, $0.5 \mathrm{~g}$ citric acid, $0.03 \mathrm{~g} \mathrm{MgSO}_{4}$ ) amended with $1 \%$ sorbitol $[52,75]$.

\section{DNA manipulation and bioinformatic analysis}

Plasmid DNA purification, PCR amplification of genes, isolation of fragments from agarose gels, cloning, restriction enzyme digestion and T4 DNA ligation were performed using standard molecular procedures [76]. DNA sequencing was performed at the Keck Center for Functional and Comparative Genomics at the University of Illinois at Urbana-Champaign. Sequence management and contig assembly were conducted using Sequencher 4.9 software. Similarity searches of nucleic acid sequences and proteins were conducted using the BLASTN and BLASTP programs at NCBI http://www.ncbi.nlm.nih.gov/ BLAST[77]. Protein domain organizations of the HKs and RRs were identified by searching the CDD with Reverse Specific Position BLAST [41] or the SMART program http:/ /smart.embl-heidelberg.de/[42]. Domain limits for proteins were also derived from the graphical output of the SMART web interface. Transmembrane segments of HKs were predicted by the TMHMM2 program http:// www.cbs.dtu.dk/services/TMHMM/[78]. Multiple sequence alignments of proteins were carried out using Clustal $\times 1.80[79]$. Sequence logos were derived from alignment of proteins belonging to corresponding HK group and created by Weblogo http://weblogo.berke ley.edu. Proteins without known domain were character- ized by using PSI-BLAST of NCBI and methods described previously [80].

\section{Construction of TCST mutants in E. amylovora by Lambda-Red recombinase}

E. amylovora stable mutants were generated by using the $\lambda$ phage recombinases as previously described [45-47]. Briefly, E. amylovora Ea1189 was transformed with plasmid pKD46 expressing recombinases red $\alpha, \beta$, and $\gamma$. The transformant Ea1189 (pKD46) was grown overnight at $28^{\circ} \mathrm{C}$, reinoculated in LB broth containing $0.1 \%$ arabinose, and grown to exponential phase $\mathrm{OD}_{600}=0.8$. Cells were collected, made electrocomponent, and stored at $80^{\circ} \mathrm{C}$. Recombination fragments consisting of a kanamycin (kan) or chloramphenical (cat) gene with its own promoter, flanked by a 50-nucleotide (nt) homology arm, were generated by PCR using plasmid pKD13 or pKD3 as a template. The primers used for generating mutants are listed in Table S2 [see Additional file 1] (primers start with B). To confirm mutants by PCR, primers (Table S2, [see Additional file 1], primers start with Z), and internal primer pairs $\mathrm{km} 1$ and $\mathrm{km} 2$ of the kan gene, $\mathrm{cm} 1$ and $\mathrm{cm} 2$ of the cat gene were used. For the resulting mutants, the majority of the coding region of each gene was replaced by the kan or cat gene, except for the first and last $50 \mathrm{nt}$. The resulting mutants were designated and listed in Table 1 and Table 3.

\section{Cloning genes/operon for complementation of TCST mutants}

For complementation of selected mutants, flanking sequences of genes or operon were used to design primers to amplify fragments of gene/or operon and their promoter sequences (Table S2, [see Additional file 1], primers with gene name). Primer pairs, with or without restriction sites were used to amplify corresponding DNA fragments from E. amylovora WT strain which contains upstream and downstream sequences of the gene or operon, and PCR fragments were cloned into either pGEM T-easy vector through A-T ligation or into a low-copy number vector pWSK29. The final plasmids were listed in Table 4. For primer pair with restriction site, DNA fragments and the vector were both digested with corresponding enzymes following amplification, and ligated together. All plasmids were introduced into E. amylovora strain by electroporation. Transformants were selected on LB plates supplemented with Ap and $\mathrm{Km}$ or $\mathrm{Cm}$. Their genotypes were confirmed by both enzymatic digestion and sequencing.

\section{Construction of promoter-GFP fusions for gene expression assays}

For gene expression assays, flanking sequences of the amsG ORF were used to design primers to amplify DNA fragments. Primer pairs amsG1-amsG2 with restriction 
Table 4: Bacterial strains and plasmids used in this study

\begin{tabular}{|c|c|c|}
\hline Strains or plasmids & Relevant characters ${ }^{\mathrm{a}}$ & Reference or source \\
\hline \multicolumn{3}{|l|}{ E. amylovora strains } \\
\hline Eall 89 & Wild type, isolated from apple & 81 \\
\hline Z2946 $4 f h D$ & fihD::Km; Kmr-insertional mutant of fihD of Eal I $89, \mathrm{Km}^{\mathrm{r}}$ & This study \\
\hline Z2945 AflhC & flhC:: Km; $\mathrm{Km}^{\mathrm{r}}$-insertional mutant of fhC of Eal I $89, \mathrm{Km}^{\mathrm{r}}$ & This study \\
\hline Z2986 $\Delta f$ liA & fliA:: Km; $\mathrm{Km}^{\mathrm{r}}$-insertional mutant of fliA of Eal I $89, \mathrm{Km}^{\mathrm{r}}$ & This study \\
\hline ZOII8Aams & $\mathrm{Km}^{\mathrm{R}}$-deletion mutant of $a m s$ operon $(\mathrm{I} 5.8 \mathrm{~kb})$ of Eal $189, \mathrm{Km}^{\mathrm{R}}$ & 47 \\
\hline \multicolumn{3}{|c|}{ 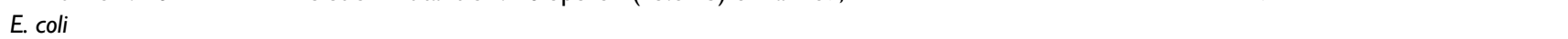 } \\
\hline $\mathrm{DHIOB}$ & $\begin{array}{l}\text { F- mcrA } \Delta(m r r-h s d R M S-m c r B C) \text { (R80lacZ } \Delta M I 5 \Delta l a c X 74 \text { recAl endAI ara } \Delta \text { I39 } \Delta(\text { ara, leu }) 7697 \\
\text { galU galK } \lambda-r p s L\left(\text { Str }^{R}\right) \text { nupG }\end{array}$ & Invitrogen, Carlsbad, CA, USA \\
\hline \multicolumn{3}{|c|}{ f } \\
\hline pKD46 & $A p^{r}, P_{B A D}$ gam bet exo pSCI0I oriTS & 45 \\
\hline PKDI3 & Kmr, FRT cat FRT PSI PS2 oriR6K rgbN & 45 \\
\hline pKD3 & $\mathrm{Cm}^{R}$, FRT cat FRT PSI PS2 oriR6K rgbN & 45 \\
\hline pGEM $^{\circledR}$ T-easy & Apr, PCR cloning vector & Promega, Madison, WI, USA \\
\hline PWSK29 & Apr, cloning vector, low copy number & 82 \\
\hline pFPV25 & Apr, GFP based promoter trap vector with a promoterless gfpmut3a gene & 83 \\
\hline PWDP4 & 721 bp Kpnl-Xbal DNA fragment containing promoter sequence of $a m s G$ gene in pFPV25 & 17 \\
\hline pWDP5 & A $3.057 \mathrm{~kb}$ PCR fragment containing grrS gene in PGEM T-easy vector & This study \\
\hline PSN4 & A $2.727 \mathrm{~kb}$ PCR fragment containing envZlompR operon in PGEM T-easy vector & This study \\
\hline pSN5 & A $2.727 \mathrm{~kb}$ PCR fragment containing envZlompR operon in PWSK29 vector & This study \\
\hline pSN6 & A $1.6 \mathrm{~kb}$ PCR fragment containing grrA gene in PGEM T-easy vector & This study \\
\hline pSN7 & A $1.463 \mathrm{~kb}$ PCR fragment containing fhDC operon in PWSK29 vector & This study \\
\hline pSN8 & A 940 bp PCR fragment containing fliA gene in PWSK29 vector & This study \\
\hline
\end{tabular}

a $\mathrm{Km}^{\mathrm{R}}, \mathrm{A} \mathrm{p}^{\mathrm{R}}, \mathrm{Cm} \mathrm{m}^{\mathrm{R}}=$ kanamycin, ampicillin and chloramphenical resistance, respectively.

sites were used to amplify 721 bp DNA fragments from $E$. amylovora WT strain, containing promoter sequences of ams $G$ gene. PCR products and the promoter trapping vector pFPV25 were both digested with BamH1 and EcoRI for ams $G$ gene. The resulting fragments were gel-purified, ligated together, and cloned to the upstream of promoterless $g f p$ gene. The final plasmids were designated as pWDP4 for amsG, and were confirmed by restriction enzyme digestion and sequencing.

\section{Immature pear virulence assays}

For E. amylovora WT and mutant strains, bacterial suspensions were grown overnight in LB broth, harvested by centrifugation, and resuspended in $0.5 \times$ sterile phosphate buffered-saline (PBS) with bacterial cells adjusted to concentrations of $\sim 1 \times 10^{3}$ to $1 \times 10^{4}$ colony-forming units $(\mathrm{CFU} / \mu \mathrm{l})\left(\mathrm{OD}_{600}=0.1\right.$ and then diluted 100 times $)$ in PBS. Immature fruits of pear (Pyrus communis L. cv. 'Bartlett') were surface-sterilized, and pricked with a sterile needle as described previously $[19,46]$. Wounded fruits were inoculated with $2 \mu \mathrm{l}$ of cell suspensions, and incubated in a humidified chamber at $26^{\circ} \mathrm{C}$. Symptoms were recorded at 2, 4, 6, and 8 days post-inoculation.

\section{CPC assay for determining amylovoran concentration}

The amylovoran concentration in supernatants of bacterial cultures was quantitatively determined by a turbidity assay with cetylpyrimidinium chloride (CPC), as previously described [50,52]. Briefly, for E. amylovora WT, mutants, and complementation strains, bacterial suspensions were grown overnight in LB broth w/o appropriate antibiotics, harvested by centrifugation, and washed with PBS three times. After the final wash, the bacterial pellet was resuspended in $200 \mu \mathrm{l}$ PBS. A total of $100 \mu$ l of bacterial suspension was inoculated into $10 \mathrm{ml}$ MBMA medium with $1 \%$ sorbitol. One ml of bacterial cells was pelleted two to three days after inoculation at $28^{\circ} \mathrm{C}$ with shaking. Following centrifugation, $50 \mu \mathrm{l} \mathrm{CPC} \mathrm{at} 50 \mathrm{mg} \mathrm{ml}^{-}$ ${ }^{1}$ was added to one $\mathrm{ml}$ supernatant. After $10 \mathrm{~min}$ of incubation at room temperature, the amylovoran concentration was determined by measuring $\mathrm{OD}_{600}$ turbidity. The final concentration of amylovoran production was normalized for a cell density of 1.0. For each strain tested, the experiment was repeated at least three times.

\section{Swarming motility assay}

For E. amylovora WT and mutant strains, bacterial suspensions were grown overnight in LB broth w/o appropriate antibiotics, harvested by centrifugation, washed with PBS once, and resuspended in $200 \mu \mathrm{l}$ PBS. Then, bacterial suspensions were diluted $10 \times$ in water, and $5 \mu$ l of the diluted bacterial suspension was plated onto the center of swarming agar plates ( $10 \mathrm{~g}$ tryptone, $5 \mathrm{~g} \mathrm{NaCl}, 3 \mathrm{~g}$ agar per 1 Liter) as previously described $[50,51]$. Swarming diameters were determined following incubation at $28^{\circ} \mathrm{C}$ for up to three days. The experiments were repeated at least three times. 


\section{Statistical analysis}

Amylovoran production and swarming motility data were undertaken a one-way ANOVA and Student-NewmanKeuls test to determine differences in means $(\mathrm{P}=0.05)$ using SAS 9.1 program.

\section{GFP reporter gene assay by flow cytometry}

The BD FACSCanto flow cytometer was used to monitor the GFP intensity of WT and mutant strains containing the corresponding promoter-gfp construct [17]. For in vitro ams $G$ gene expression, WT and mutants containing the ams $G$ promoter-GFP fusion plasmid were grown in LB overnight, harvested, and resuspended in water. Bacterial suspensions were re-inoculated in MBMA broth with 1\% sorbitol and grown at $28^{\circ} \mathrm{C}$ with shaking for up to three days. Bacterial cultures were then harvested by centrifugation, washed once with PBS, and then resuspended in PBS for flow cytometry assay. Flow cytometry was performed on a BD LSRII 10 parameter multilaser analyzers (BD Bioscience, San Jose, CA). For both cases, data were collected for a total of 100,000 events and statistically analyzed by gating using flow cytometry software FCS Express V3 (De Novo Software, LA, CA). A geometric mean was calculated for each sample. Each treatment was performed in triplicate and each experiment was repeated three times.

\section{Abbreviations}

CDD: Conserved Domain Databases; CPC: cetylpyrimidinium chloride; EAL: Type I c-di-GMP phosphodiesterase; EPS: extracellular polysaccharide; HisKA: histidine kinase domain; HK: histidine kinase; HMM: Hidden Markov Model; Hpt: histidine phosphotransfer; HTH: helix-turn-helix; GGDEF: diguanylate cyclase; PAS: initially found in PER, ARNT, and SIM proteins; REC: receiver domain; RR: response regulator; TCST: two-component signal transduction system; T3SS: type III secretion system.

\section{Authors' contributions}

YFZ designed and coordinated the project, YFZ, DPW, and SN performed the experiments and analyzed the data; GWS and SSK contributed reagents/materials, analyzed and discussed the results; YFZ wrote the manuscript and GWS and SSK critically read the manuscript. All authors have read and approved the final manuscript.

\section{Additional material}

\section{Additional File 1}

Comparison and classification of TCSTs in E. amylovora and other related enterobacteria and primers used in this study. The file contains two tables. Table S1 compares and classifies TCSTs in E. amylovora and other related enterobacteria; Table S2 lists primers used in this study. Click here for file

[http://www.biomedcentral.com/content/supplementary/14712164-10-245-S1.pdf]

\section{Additional File 2}

Structural classification of histidine kinases, hypersensitive response of HrpXYS mutants in tobacco and schematic map of HrpXYS operon. The file contains two figures. Figure S1 shows structural classification of histidine kinases (HKs) based on phosphorylation sites (H-boxes); Figure S2 shows hypersensitive responses (HR) on tobacco for WT, $\Delta T 3 S S$ [47], hrpX, hrpY, hrpXY, and hrpXYS mutants (Figure S2A) and a schematic map of the HrpXYS operons (Figure S2B).

Click here for file

[http://www.biomedcentral.com/content/supplementary/14712164-10-245-S2.pdf]

\section{Acknowledgements}

We are grateful to Dr. Barry Wanner at Purdue University, Dr. S. Kushner at University of Georgia, and Dr. R. Valdivia at Duke University for providing the pKD46, pKDI3 and pKD3, pWSK29 and pFPV25 plasmids, respectively. We would like to thank Dr. Virginia Stockwell at Oregon State University for providing part of the immature pear fruits used in this experiment. We are also grateful to Dr. Steve Beer at the Cornell University and the Sanger Institute for the genome sequence of $E$. amylovora strain Ea273. This work was supported by the USDA Cooperative State Research, Education and Extension Service (Hatch project \# Illu-802-317) and the Agricultural Experiment Stations of Illinois and Michigan.

\section{References}

I. Hoch JA, Silhavy TJ, eds: Two-component signal transduction Washington DC: ASM Press; 1995.

2. Inouye M, Dutta R, eds: Histidine Kinases in Signal Transduction New York: Academic Press; 2003.

3. Alex LA, Simon MI: Protein histidine kinases and signal transduction in prokaryotes and eukaryotes. Trends Genet 1994, 10:133-138.

4. Stock AM, Robinson VL, Goudreau PN: Two-component signal transduction. Annu Rev Biochem 2000, 69:183-215.

5. Wolanin P, Thomason PA, Stock JB: Histidine protein kinases: key signal transducers outside the animal kingdom. Genome Biol 2002, 3:3013.

6. Mizuno T: Compilation of all genes encoding two-component phosphotransfer signal transducers in the genome of Escherichia coli. DNA Res 1997, 4:161-168.

7. Beier D, Gross R: Regulation of bacterial virulence by twocomponent systems. Curr Opin Microbiol 2006, 9: I- 10.

8. Lavin JL, Kiil K, Resano O, Ussery DW, Oguiza JA: Comparative genomic analysis of two-component regulatory proteins in Pseudomonas syringae. BMC Genomics 2007, 8:397.

9. Qian W, Han Z, He C: Two-component signal transduction systems of Xanthomonas spp.: A lesson from genomics. Mol PlantMicrobe Interact 2008, 21 : 15I-161.

10. Mole BM, Baltrus DA, Dangl JL, Grant SR: Global virulence regulation networks in phytopathogenic bacteria. Trends Microbiol 2007, I 5:363-371.

II. Brencic A, Winans SC: Detection and response to signals involved in host-microbe interactions by plant associated bacteria. Microbiol Mol Biol Rev 2005, 69: I55-194.

12. Heeb S, Haas D: Regulatory roles of the GacS/GacA two-component system in plant-associated and other gram-negative bacteria. Mol Plant-Microbe Interact 200I, I 4:135I-1363.

13. Qian W, Han Z, Tao J, He C: Genome-scale mutagenesis and phenotypic characterization of two-component signal transductions of Xanthomonas campestris pv. campestris ATCC339 I3. Mol Plant-Microbe Interact 2008, 2 1:। I 28-I I 38.

14. Vanneste JL, ed: Fire blight, the disease and its causative agent, Erwinia amylovora Wallingford UK: CABI Publ; 2000.

15. He SY, Nomura K, Whittam TS: Type III protein secretion mechanism in mammalian and plant pathogens. Biochem Biophys Acta 2004, 1694:181-206. 
16. Oh CS, Beer SV: Molecular genetics of Erwinia amylovora involved in the development of fire blight. FEMS Microbiol Let 2005, 253:185-192.

17. Wang DP, Korban SS, Zhao YF: The Rcs phosphorelay system is essential for pathogenicity in Erwinia amylovora. Mol Plant Pathol 2009, 10:277-290.

18. Wei ZM, Kim JF, Beer SV: Regulation of hrp genes and type III protein secretion in Erwinia amylovora by HrpX/HrpY, a novel two component system, and HrpS. Mol Plant-Microbe Interact 2000, I3:|25|-1262.

19. Zhao YF, Blumer SE, Sundin GW: Identification of Erwinia amylovora genes induced during infection of immature pear tissue. J Bacteriol 2005, I 87:8088-8103.

20. Lapouge K, Schubert M, Allain FHT, Haas D: Gac/Rsm signal transduction pathways of $\gamma$-proteobacteria: from RNA recognition to regulation of social behaviour. Mol Microbiol 2008, 67:24I-253.

21. Forst S, Delgado J, Inouye M: Phosphorylation of OmpR by the osmosensor EnvZ modulates expression of the ompF and ompC genes in Escherichia coli. Proc Natl Acad Sci USA 1989, 86:6052-6056.

22. Park D, Forst S: Co-regulation of motility, exoenzyme and antibiotic production by the EnvZ-OmpR-FlhDC-FliA pathway in Xenorhabus nematophila. Mol Microbiol 2006, 61:1397-1412.

23. Feng $X$, Oropeza $R$, Kenney LJ: Dual regulation by phosphoOmpR of ssrA/B gene expression in Salmonella pathogenicity island 2. Mol Microbiol 2003, 48: I I I - I | 43.

24. Garmendia J, Beuzon CR, Ruiz-Albert J, Holden DW: The roles of SsrA-SsrB and OmpR-EnvZ in the regulation of genes encoding the Salmonella typhimurium SPI-2 type III secretion system. Microbiology 2003, I49:2385-2396.

25. Kim CC, Falkow S: Delineation of upstream signaling events in the Salmonella pathogenicity island 2 transcriptional activation pathway. J Bacteriol 2004, I 86:4694-4704.

26. Lee AK, Detweiler CS, Falkow S: OmpR regulates the two-component system SsrA-SsrB in Salmonella pathogenicity island 2. J Bacteriol 2000, I 82:77|-78I.

27. Brzostek K, Brzostkowska M, Bukowska I, Karwicka E, Raczkowska A: OmpR negatively regulates expression of invasion in Yersinia enterocolitica. Microbiology 2007, I 53:2416-2425.

28. Xiao Y, Lan L, Yin C, Deng X, Baker D, Zhou J, Tang X: Two-component sensor RhpS promoters induction of Pseudomonas syringae type III secretion system by repressing negative regulator RhpR. Mol Plant-Microbe Interact 2007, 20:223-234.

29. Yang S, Peng Q, Zhang Q, Yi X, Choi CJ, Reedy RM, Charkowski AO, Yang C: Dynamic regulation of GacA in type III secretion, pectinase gene expression, pellicle formation, and pathogenicity of Dickeya dadantii (Erwinia chrysanthemi 3937). Mol Plant-Microbe Interact 2008, 2 I : 133-142.

30. Lebeau A, Reverchon S, Gaubert S, Kraepiel Y, Simond-Cote E, Nasser W, Gijsegem F: The GacA global regulator is required for the appropriate expression of Erwinia chrysanthemi 3937 pathogenicity genes during plant infection. Environ Microbiol 2008, 1 0:545-559.

31. Marutani M, Taguchi F, Ogawa Y, Hossain Md M, Inagaski Y, Toyoda K, Shiraishi T, Ichinose $Y$ : Gac two-component system in Pseudomonas syringae pv. tabaci is required for virulence but not for hypersensitive reaction. Mol Genet Genomics 2008 , 279:313-322.

32. Cui Y, Chatterjee A, Yang H, Chatterjee AK: Regulatory network controlling extracellular proteins in Erwinia carotovora subsp. carotovora: FIhDC, the master regulator of flagellar genes, activates rsmB regulatory RNA production by affecting gacA and hexA (IrhA) expression. J Bacteriol 2008 190:4610-4623.

33. Chatterjee A, Cui $Y$, Yang $H$, Collmer A, Alfano JR, Chatterjee AK: GacA, the response regulator of a two-component system, acts as a master regulator in Pseudomonas syringae pv. tomato DC3000 by controlling regulatory RNA, transcriptional activators, and alternative sigma factors. Mol PlantMicrobe Interact 2003, 16:1106-III7.

34. Tang X, Xiao Y, Zhou J: Regulation of the Type III secretion system in phytopathogenic bacteria. Mol Plant-Microbe Interact 2006, 19:1159-1166.
35. Yang S, Peng Q, Francisco MS, Wang Y, Zeng Q, Yang C: Type III secretion system genes of Dickeya dadantii 3937 are induced by plant phenolic acids. PLoS One 2008, 3:e2973.

36. Gonzalez N, Heeb S, Valverde C, Reimmann C, Junier T, Haas D: Genome-wide search reveals a novel GacA-regulated small RNA in Pseudomonas species. BMC Genomics 2008, 9:167.

37. Bocsanczy AM, Perna NT, Biehl B, Glasner JD, Cartinhour SW, Schneider DJ, DeClerck GA, Sebaihia M, Parkhill J, Bentley S, Beer SV: Contributions of the genome sequence of Erwinia amylovora to the fire blight community. Acta Hortic 2008, 793: I63-I70.

38. Kube M, Migdoll AM, Muller I, Kuhl H, Beck A, Reinhardt R, Geider $\mathrm{K}$ : The genome of Erwinia tasmaniensis strain $\mathrm{EtI} / 99$, a nonpathogenic bacterium in the genus Erwinia. Environ Microbiol 2008, 10:221 I-2222.

39. Yap MN, Yang C, Charkowski AO: The response regulator HrpY of Dickeya dadantii 3937 regulates virulence genes not linked to the hrp cluster. Mol Plant-Microbe Interact 2008, 2 I:304-3 I4.

40. Kim D, Forst S: Genomic analysis of the histidine kinase family in bacteria and archaea. Microbiology 2001, I47:1 197-1212.

4I. Marchler-Bauer A, Anderson JB, Cherukuri PF, DeWeese-Scott C Geer LY, Gwadz M, He S, Hurwitz DI, Jackson JD, Ke Z, Lanczycki CJ, Liebert CA, et al.: CDD: A Conserved Domain Database for protein classification. Nucleic Acids Res 2005, 33:DI92-DI 96.

42. Letunic I, Copley RR, Pils B, Pinkert S, Schultz J, Bork P: SMART 5: Domains in the context of genomes and networks. Nucleic Acids Res 2006, 34:D257-D260.

43. Galperin MY: Structural classification of bacterial response regulators: Diversity of output domains and domain combinations. I Bacteriol 2006, I 88:4|69-4I82.

44. Fouhy Y, Lucey JF, Ryan RP, Dow JM: Cell-cell signaling, cyclic diGMP turnover and regulation of virulence in Xanthomonas campestris. Res Microbiol 2006, I 57:899-904.

45. Datsenko KA, Wanner BL: One-step inactivation of chromosomal genes in Escherichia coli K-I 2 using PCR products. Proc Natl Acad Sci USA 2000, 97:6640-6645.

46. Zhao YF, He SY, Sundin GW: The Erwinia amylovora avrRpt2 gene contributes to virulence on pear and AvrRpt2 ${ }_{E A}$ is recognized by Arabidopsis RPS2 when expressed in Pseudomonas syringae. Mol Plant-Microbe Interact 2006, 1 9:644-654.

47. Zhao YF, Sundin GW, Wang DP: Construction and analysis of pathogenicity island deletion mutants of Erwinia amylovora. Can I Microbiol 55:457-464

48. Bogdanove AJ, Bauer DW, Beer SV: Erwinia amylovora secretes DspE, a pathogenicity factor and functional AvrE homolog, through the Hrp (type III secretion) pathway. J Bacteriol I 998 I 80:2244-2247.

49. Bereswill S, Geider K: Characterization of the rcsB gene from Erwinia amylovora and its influence on exoploysaccharide synthesis and virulence of the fire blight pathogen. J Bacteriol 1997, I 79: |354-6I.

50. Hildebrand M, Aldridge $P$, Geider K: Characterization of hns genes from Erwinia amylovora. Mol Genet Genomics 2006, 275:310-319.

5I. Skerker JM, Prasol MS, Perchuk BS, Biondi EG, Laub MT: Two-component signal transduction pathways regulating growth and cell cycle progression in a bacterium: A system-level analysis. PLoS Biol 2005, 3:e334.

52. Bellemann P, Bereswill S, Berger S, Geider K: Visualization of capsule formation by Erwinia amylovora and assays to determine amylovoran synthesis. Int J Biol Macromol I994, I 6:290-296.

53. Toth IK, Pritchard L, Birch PRJ: Comparative genomics reveals what makes an enterobacterial plant pathogen. Annu Rev Phytopathol 2005, 44:305-306.

54. Majdalani N, Gottesman S: The Rcs phosphorelay: a complex signal transduction system. Annu Rev Microbiol 2006, 59:379-405

55. D'Souza M, Glass EM, Syed M, Zhang $Y$, Rodriguez A, Maltsev N, Galperin MY: Sentra: a database of signal transduction proteins for comparative genome analysis. Nucleic Acids Res 2007, 35:D27I-273.

56. Galperin MY: Bacterial signal transduction network in a genomic perspective. Environ Microbiol 2004, 6:552-567.

57. Ulrich LE, Zhulin IB: MiST: a microbial signal transduction database. Nucleic Acids Res 2007, 35:D386-390.

58. Galperin MY, Nikolskaya AN, Koonin EV: Novel domains of the prokaryotic two-component signal transduction systems. FEMS Microbiol Lett 200I, 203: I I-2I. 
59. Nissien RM, Ytterberg AJ, Bogdanove AJ, van Wijk KJ, Beer SV: Analyses of the secretomes of Erwinia amylovora and selected $h r p$ mutants reveal novel type III secreted proteins and an effect of HrpJ on extracellular harpin levels. Mol Plant Pathol 2007, 8:55-67.

60. Oh CS, Kin JY, Beer SV: The Hrp pathogenicity island of Erwinia amylovora and identification of three novel genes required for systemic infection. Mol Plant Pathol 2005, 6: I25-138.

61. Merighi M, Majerczak DR, Stover EH, Coplin DL: The HrpX/Y twocomponent system activates $h r p S$ expression, the first step in the regulatory cascade controlling the Hrp regulon in Pantoea stewartii subsp. stewartii. Mol Plant-Microbe Interact 2003 I 6:238-248

62. Merighi M, Majerczak DR, Coplin DL: A novel transcriptional autoregulatory loop enhances expression of the Pantoea stewartii subsp. stewartii Hrp Type III secretion system. FEMS Microbiol Lett 2005, 243:479-487.

63. Merighi M, Majerczak DR, Zianni M, Tessanne K, Coplin DL: Molecular characterization of Pantoea stewartii subsp. stewartii HrpY, a conserved response regulator of the hrp type II secretion system, and its interaction with the hrpS promoter. J Bacteriol 2006, I 88:5089-5100.

64. Lan L, Deng X, Zhou J, Tang X: Genome-wide gene expression analysis of Pseudomonas syringae pv. tomato DC3000 reveals overlapping and distinct pathways regulated by $h r p L$ and hrpRS. Mol Plant-Microbe Interact 2006, I 9:976-987.

65. Kelm O, Kiecker C, Geider K, Bernhard F: Interaction of the regulator proteins RcsA and RcsB with the promoter of the operon for amylovoran biosynthesis in Erwinia amylovora. Mol Gen Genet 1997, 256:72-83.

66. Fraser GM, Hughes C: Swarming motility. Curr Opin Microbiol 1999, 2:630-635.

67. Harshey RM: Bacterial motility on a surface: many ways to a common goal. Annu Rev Microbiol 2003, 57:249-273.

68. Jarrell $\mathrm{KF}, \mathrm{McBride} \mathrm{MJ}$ : The surprisingly diverse ways that prokaryotes move. Nat Rev Microbiol 2008, 6:466-476.

69. Kaiser D: Bacterial swarming: a re-examination of cell movement patterns. Curr Biol 2007, I 7:R56I-R570.

70. Overhage J, Bains M, Brazas MD, Hancock RE: Swarming of Pseudomonas aeroginosa is a complex adaptation leading to increased production of virulence factors and antibiotic resistance. J Bacteriol 2008, 190:267|-2679.

7I. McCarter LL: Regulation of flagella. Curr Opin Microbiol 2006, 9:180-186.

72. Wang Q, Suzuki A, Mariconda S, Porwollik S, Harshy RM: Sensing wetness: a new role for the bacterial flagellum. EMBO J 2005 , 24:2034-2042.

73. Lai S, Tremblay J, Deziel E: Swarming motility: a multicellular behaviour conferring antimicrobial resistance. Environ Microbiol 2009, I I (I): I26-36

74. Chen BG, Turner $L$, Berg HC: The wetting agent required for swarming in Salmonella enterica serovar Typhimurium is not a surfactant. J Bacteriol 2007, I 89:8750-8753.

75. Torriani A: Influence of inorganic phosphate in the formation of phosphatases by Escherichia coli. Biochim Biophys Acta 1960 , 38:460-479.

76. Sambrook J, Fritsch EF, Maniatis T: Molecular cloning: a laboratory manual Cold Spring Harbor, N.Y.: Cold Spring Harbor Laboratory Press; 1989

77. Altschul SF, Madden TL, Schaffer AA, Zhang J, Zhang Z, Miller W, Lipman DJ: Gapped BLAST and PSI-BLAST: a new generation of protein database search programs. Nucleic Acids Res 1997, 25:3389-3402.

78. Krogh A, Larsson B, von Heijne G, Sonnhammer EL: Predicting transmembrane protein topology with a hidden Markov model: Application to complete genomes. J Mol Biol 200I, 305:567-580.

79. Thompson JD, Higgins DG, Gibson TJ: CLUSTAL W: improving the sensitivity of progressive multiple sequence alignment through sequence weighting, position-specific gap penalties and weight matrix choice. Nucleic Acid Res 1994, 22:4673-4680.

80. Galperin MY, Nikolskaya AN: Identification of sensory and signal-transducing domains in two-component signaling systems. Methods Enzymol 2007, 422:47-74.
81. Burse A, Weingart H, Ullrich MS: NorM, an Erwinia amylovora multidrug efflux pump involved in in vitro competition with other epiphytic bacteria. Appl Environ Microbiol 2004, 70:693-703.

82. Wang RF, Kushner SR: Construction of versatile low-copynumber vectors for cloning, sequencing and gene expression in Escherichia coli. Gene 1991, 100:195-199.

83. Valdivia RH, Falkow S: Fluorescence-based isolation of bacterial genes expressed within host cells. Science 1997, 277:2007-20 I I.

Publish with Bio Med Central and every scientist can read your work free of charge

"BioMed Central will be the most significant development for disseminating the results of biomedical research in our lifetime. "

Sir Paul Nurse, Cancer Research UK

Your research papers will be:

- available free of charge to the entire biomedical community

- peer reviewed and published immediately upon acceptance

- cited in PubMed and archived on PubMed Central

- yours - you keep the copyright 